\title{
Does exceeding the critical loads for nitrogen alter nitrate leaching, the nutrient status of trees and their crown condition at Swiss Long-term Forest Ecosystem Research (LWF) sites?
}

\author{
Anne Thimonier - Elisabeth Graf Pannatier • \\ Maria Schmitt • Peter Waldner · Lorenz Walthert • \\ Patrick Schleppi • Matthias Dobbertin • \\ Norbert Kräuchi
}

Received: 30 January 2009/Revised: 14 October 2009/Accepted: 28 October 2009/Published online: 24 November 2009

(c) Springer-Verlag 2009

\begin{abstract}
Nitrogen (N) deposition exceeds the critical loads for this element in most parts of Switzerland apart from the Alps. At 17 sites ( 8 broadleaved stands, 8 coniferous stands, and 1 mixed stand) of the Swiss Long-term Forest Ecosystem Research network, we are investigating whether $\mathrm{N}$ deposition is associated with the $\mathrm{N}$ status of the forest ecosystems. $\mathrm{N}$ deposition, assessed from throughfall measurements, was related to the following indicators: (1) nitrate leaching below the rooting zone (measured on a subset of 9 sites); (2) the $\mathrm{N}$ nutrition of the forest stand based on foliar analyses (16 sites); and (3) crown defoliation, a non specific indicator of tree vitality (all 17 sites). Nitrate leaching ranging from about 2 to $16 \mathrm{~kg} \mathrm{~N}^{-1} \mathrm{a}^{-1}$ was observed at sites subjected to moderate to high total $\mathrm{N}$ deposition $\left(>10 \mathrm{~kg} \mathrm{ha}^{-1} \mathrm{a}^{-1}\right)$. The $\mathrm{C} / \mathrm{N}$ ratio of the soil organic layer, or, when it was not present, of the upper $5 \mathrm{~cm}$ of the mineral soil, together with the pool of organic carbon in the soil, played a critical role, as previous studies have also found. In addition, the humus type may need to be considered as well. For instance, little nitrate leaching $\left(<2 \mathrm{~kg} \mathrm{~N} \mathrm{ha}^{-1} \mathrm{a}^{-1}\right)$ was recorded at the Novaggio site,
\end{abstract}

This publication originated from the conference on "Impacts of Air Pollution and Climate Change on Forest Ecosystems" with emphasis on "Air Pollution and Climate Change at Contrasting Altitude and Latitude", held 7-12 September 2008 in Murten Switzerland; organized by IUFRO \& Swiss Federal Institute for Forest, Snow and Landscape Research (WSL).

Communicated by R. Matyssek.

A. Thimonier $(\bowtie) \cdot$ E. Graf Pannatier · M. Schmitt .

P. Waldner - L. Walthert - P. Schleppi - M. Dobbertin .

N. Kräuchi

WSL-Swiss Federal Institute for Forest, Snow and Landscape Research, Zürcherstrasse 111, 8903 Birmensdorf, Switzerland e-mail: thimonier@wsl.ch which is subjected to high total $\mathrm{N}$ deposition ( $>30 \mathrm{~kg} \mathrm{ha}^{-1} \mathrm{a}^{-1}$ ) but characterized by a $\mathrm{C} / \mathrm{N}$ ratio of 24 , large organic $\mathrm{C}$ stocks, and a moder humus type. Foliar $\mathrm{N}$ concentrations correlated with $\mathrm{N}$ deposition in both broadleaved and coniferous stands. In half of the coniferous stands, foliar $\mathrm{N}$ concentrations were in the deficiency range. Crown defoliation tended to be negatively correlated with $\mathrm{N}$ concentrations in the needles. In the majority of the broadleaved stands, foliar $\mathrm{N}$ concentrations were in the optimum nutritional range or, on one beech plot with high total $\mathrm{N}$ deposition $\left(>25 \mathrm{~kg} \mathrm{ha}^{-1} \mathrm{a}^{-1}\right)$, above the optimum values. There was no correlation between the crown defoliation of broadleaved trees and foliar concentrations.

Keywords Critical loads for nitrogen - Forest . Atmospheric deposition - Nitrate leaching .

Foliar concentrations $\cdot$ Crown defoliation

\section{Introduction}

Emissions of oxidized and reduced nitrogen $(\mathrm{N})$ in Europe have been reduced during the past 15-20 years, but they remain largely above the targeted emission levels set by the 1999 UNECE Gothenburg Protocol (Lövblad et al. 2004). In Switzerland, emissions of nitrogen oxides (NOx) reached a peak in the mid 1980s, and have since mostly decreased, but they are still $\sim 60 \%$ higher today than in 1960 (EKL 2005). Emissions of ammonia $\left(\mathrm{NH}_{3}\right)$ reached a peak in 1980, with levels twice as high as those at the beginning of the twentieth century. $\mathrm{NH}_{3}$ emissions have decreased since then but are still higher than in the early 1900s (EKL 2005). Nitrogen can thus be expected to continue to have a significant impact on the environment in the coming decades. 
Under pristine or low nitrogen deposition conditions, the nitrogen cycle in temperate forest ecosystems functions without mineral $\mathrm{N}$ losses (Tamm 1991). Nitrogen is usually a limiting factor of plant growth in natural or semi-natural ecosystems (Vitousek and Howarth 1991). Enhanced nitrogen deposition due to high emission levels can thus have a fertilizing effect and stimulate forest growth at sites where $\mathrm{N}$ is limiting (de Vries et al. 2008; Laubhann et al. 2009; Solberg et al. 2009). An enhanced N supply may stimulate the production of above-ground biomass and result in increased nitrogen contents in foliage (Aber et al. 1989, 1998). Relationships between $\mathrm{N}$ supply and nutritional status have been found for forest stands across deposition gradients (e.g. Boggs et al. 2007; Flückiger and Braun 1998; Tietema and Beier 1995) or following nitrogen addition (e.g. Boxman et al. 1998a; McNulty et al. 2005). Some studies have shown, however, that root growth remains comparatively limited (e.g. Flückiger and Braun 1998; van Dijk et al. 1990), which, in turn, may increase the susceptibility of the trees to drought. Furthermore, nutrient deficiencies or imbalances relative to $\mathrm{N}$ may arise, and sensitivity to frost, insects, and fungi may increase (e.g. Flückiger and Braun 1998; Roelofs et al. 1985). In the soil, elevated nitrogen deposition may lead not only to an accumulation of $\mathrm{N}$ and thus to a lower $\mathrm{C} / \mathrm{N}$ ratio (Schleppi et al. 2004), but also to the release of protons in the soil solution through $\mathrm{NH}_{4}{ }^{+}$uptake or nitrification. These two processes both have a net acidifying effect if $\mathrm{NO}_{3}{ }^{-}$produced by the nitrification process is leached rather than taken up by the plants or microorganisms. Nutritional base cations $\left(\mathrm{Ca}^{2+}, \mathrm{Mg}^{2+}, \mathrm{K}^{+}\right)$can then be mobilized from the exchange complex of the soils. The mobilized base cations can be taken up or washed out below the rooting zone with the mobile anions $\mathrm{NO}_{3}{ }^{-}$and $\mathrm{SO}_{4}{ }^{2-}$.

Increased $\mathrm{NO}_{3}{ }^{-}$leaching from the rooting zone occurs when the forest ecosystem reaches "nitrogen saturation", defined as the stage at which nitrogen availability exceeds the capacity of plant and soil microbes to retain $\mathrm{N}$ (Aber et al. 1989). In temperate forests, nitrate leaching above $5 \mathrm{~kg} \mathrm{~N} \mathrm{ha}{ }^{-1} \mathrm{a}^{-1}$ or elevated nitrate concentrations in seepage water $\left(>1 \mathrm{mg} \mathrm{N}^{-1}\right)$ were found to occur mainly at sites receiving annual throughfall fluxes of $\mathrm{N}$ above $10 \mathrm{~kg} \mathrm{ha}^{-1} \mathrm{a}^{-1}$ (Dise and Wright 1995; Gundersen 1995). However, nitrate leaching depends not only on nitrogen input, but also on the $\mathrm{C} / \mathrm{N}$ ratio of the humus-rich soil layers. $\mathrm{C} / \mathrm{N}$ ratios below 25 are indicative of a high risk of nitrate leaching, while no or little leaching is usually recorded at sites with C/N ratios above 30 (Dise et al. 1998; Gundersen et al. 2006; Kristensen et al. 2004; van der Salm et al. 2007).

The long-term effects of nitrogen deposition on forest ecosystems can be assessed using the concept of "critical loads". Critical loads are defined as a quantitative estimate of an exposure to a deposition below which significant harmful effects on specified sensitive elements of the environment do not occur according to current knowledge (Nilsson and Grennfelt 1988). Two approaches were proposed to determine critical loads for nitrogen as a nutrient. The first approach (steady state mass balance method SMB) is based on the nitrogen saturation concept. If $\mathrm{N}$ deposition exceeds the total combined plant and microbial demand, then enhanced nitrate leaching can be expected (UBA 1996). The second approach is empirical and is based on data obtained from controlled chamber and field experiments, chemical analyses, comparisons of vegetation composition in time and space, ecosystem models, and biological knowledge (Grennfelt and Thörnelöf 1992; Rihm 1996; Rihm and Kurz 2001).

Thimonier et al. (2005), Schmitt et al. (2005) and Waldner et al. (2007) showed that the $\mathrm{N}$ deposition between 1995 and 2001 was in the range or exceeded the critical loads at the majority of the sites of the Swiss Long-term Forest Ecosystem Research network. Here, we explore the impact of $\mathrm{N}$ deposition by investigating the relation across these sites between the exceedance of the critical load for nitrogen and two indicators of the nitrogen status of the forest stand: $\mathrm{NO}_{3}{ }^{-}$leaching and foliar $\mathrm{N}$ concentrations. Further, we examine whether a relationship exists between the nitrogen status and crown condition, a (non-specific) indicator of tree vitality. According to the theory of $\mathrm{N}$ saturation (Aber et al. 1989, 1998), we formulated the following hypotheses:

1. At sites where (i) $\mathrm{N}$ deposition is high $(\geq 10 \mathrm{~kg}$ $\mathrm{ha}^{-1} \mathrm{a}^{-1}$ in throughfall) and (ii) the $\mathrm{C} / \mathrm{N}$ ratio of the forest floor is below 25 (Gundersen et al. 2006), $\mathrm{NO}_{3}{ }^{-}$ will be leached from the rooting zone.

2. For a given tree species, foliar $\mathrm{N}$ concentrations will be higher at sites subjected to high $\mathrm{N}$ deposition than at sites with lower $\mathrm{N}$ deposition.

3. High $\mathrm{N}$ deposition associated with the exceedance of critical loads could be a stress factor that might result in the crown condition deteriorating.

\section{Methods}

The data on atmospheric deposition, concentrations in the soil solution, foliar concentrations, and crown condition were collected at all 17 sites or parts of them belonging to the Swiss Long-term Forest Ecosystem Research network (LWF). LWF is part of the Level II network of the International Co-operative Programme on Assessment and Monitoring of Air Pollution Effects on Forests (ICP-Forests) (e.g. de Vries et al. 2003). The 17 sites are distributed across the main regions of Switzerland, from the Jura Mountains to the southern side of the Alps (Table 1; Fig. 1). Elevations range from $480 \mathrm{~m}$ a.s.l. in the Swiss Plateau (Vordemwald) to $1,900 \mathrm{~m}$ in the eastern Alps (National Park). The sites cover a broad range of soil 


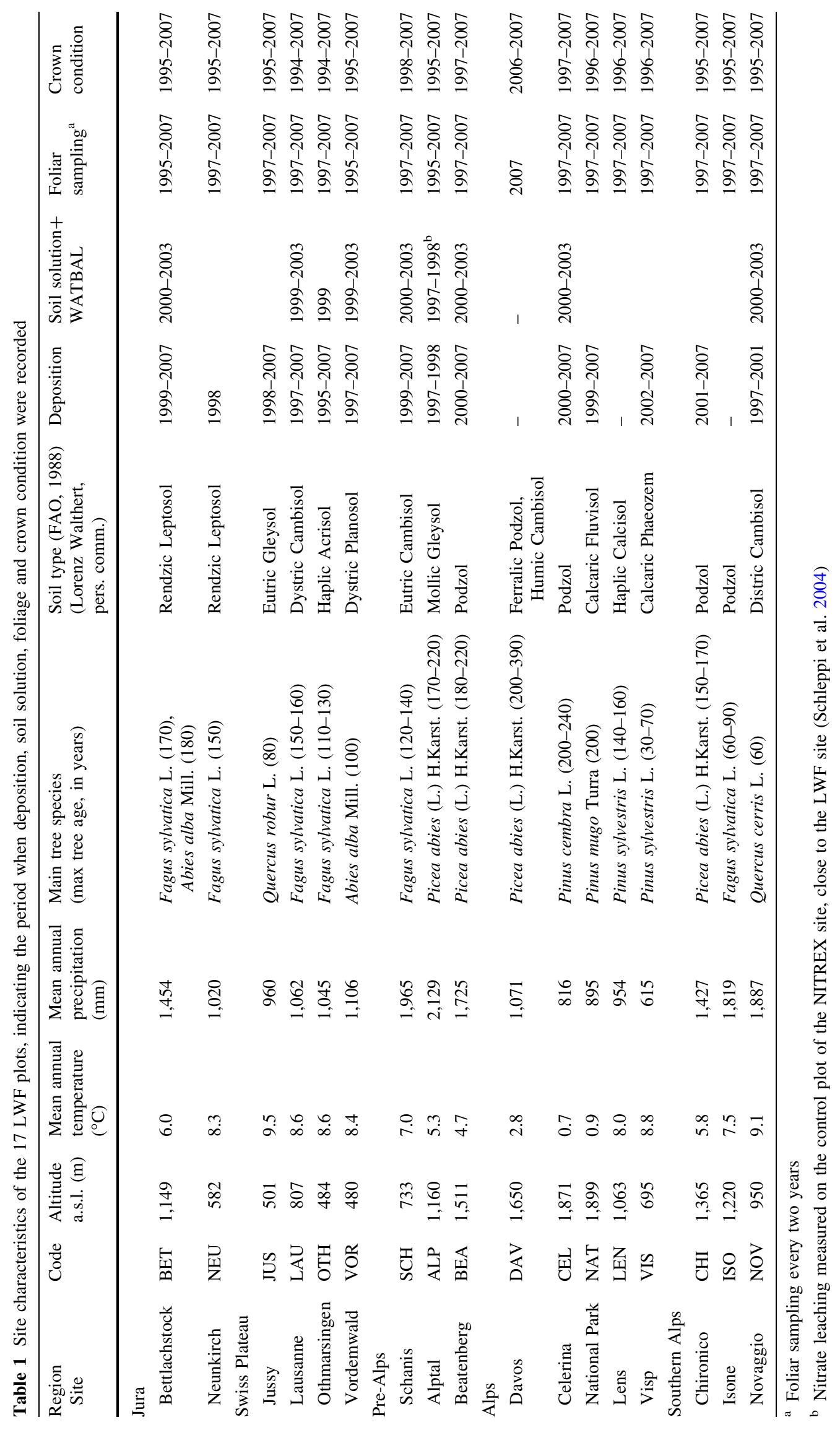


Fig. 1 Location of the 17 study sites. These sites belong to the Swiss Long-term Forest Ecosystem Research ( $L W F)$ network

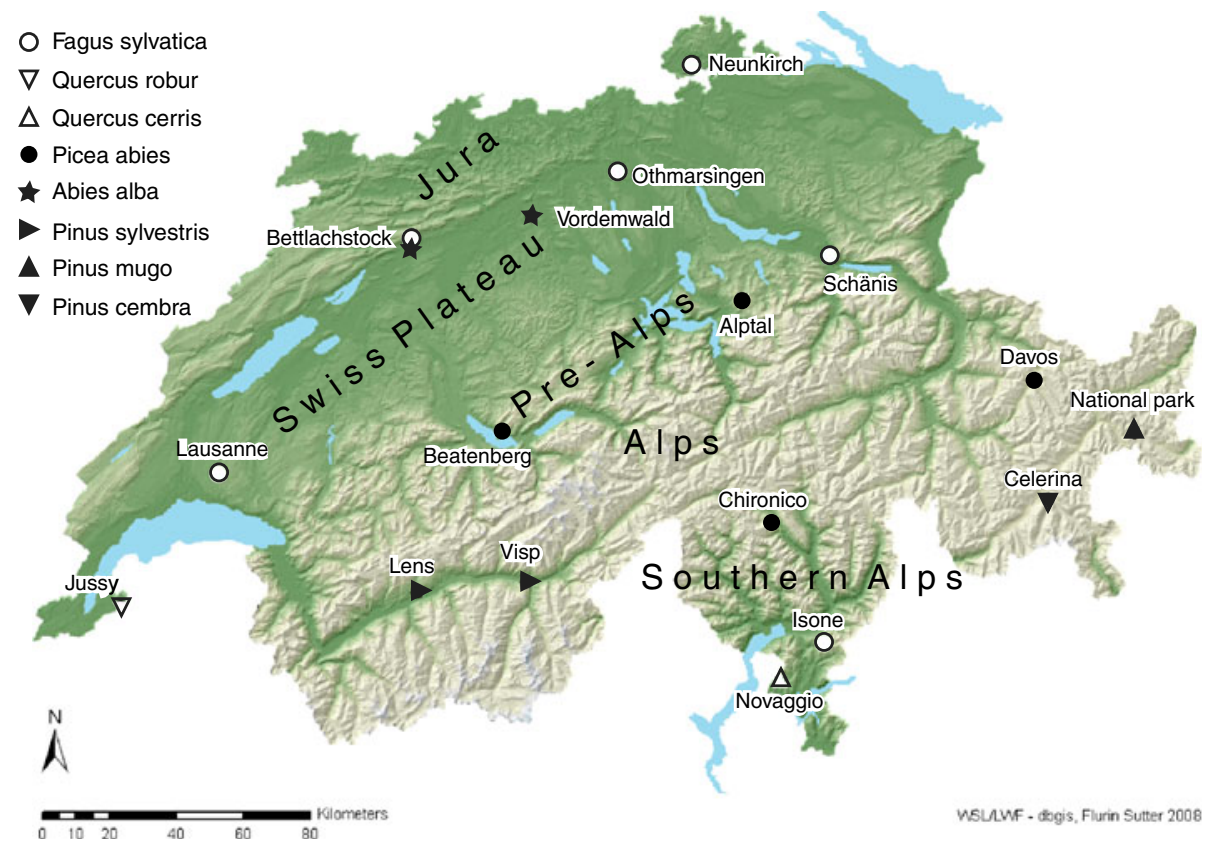

conditions, from calcareous soils to podzols. Eight main tree species are represented, including beech (Fagus sylvatica L.) (6 sites) and Norway spruce (Picea abies (L.) Karst.) (4 sites).

Nitrogen deposition and critical loads

Atmospheric deposition was quantified on 14 sites for at least 1 year using the throughfall method, which relies on the parallel sampling of throughfall and precipitation in an open area close to the forest stand. A detailed description of the sampling procedures is given in Thimonier et al. (2005). Precipitation in the open area was collected with three continuously open funnel-type $\left(100 \mathrm{~cm}^{2}\right.$ opening) polyethylene collectors (bulk precipitation). At the sites where abundant snowfall can be expected (Bettlachstock, Beatenberg, Schänis, Celerina, National Park, Lausanne, Chironico, and Novaggio), the funnel-type collectors were replaced by a single bucket-type snow collector $(30 \mathrm{~cm}$ diameter) in winter.

Throughfall was sampled with 16 funnel-type collectors of the same type as the collectors used in the open area. The collectors were systematically distributed over two $43 \times 43 \mathrm{~m}$ areas: an intensive monitoring subplot, on which other core measurements are carried out, and a mirror subplot. The 16 funnel-type collectors were replaced by four bucket-type collectors in winter at all the sites where abundant snowfall was expected (see above) apart from Chironico, where sampling is stopped in winter.

The samples were collected once every 2 weeks (4 weeks at Celerina and Bettlachstock in the winter). They were sent by post or brought directly to the laboratory. The chemical analyses were performed on filtered samples $(0.45 \mu \mathrm{m})$. Ammonium $\left(\mathrm{NH}_{4}{ }^{+}\right)$was determined colorimetrically through automated flow injection analysis. Calcium $\left(\mathrm{Ca}^{2+}\right)$, magnesium $\left(\mathrm{Mg}^{2+}\right)$, potassium $\left(\mathrm{K}^{+}\right)$, and sodium $\left(\mathrm{Na}^{+}\right)$were determined by inductively coupled plasma-atomic emission spectrometry (ICP-AES). Nitrate $\left(\mathrm{NO}_{3}{ }^{-}\right)$, sulphate $\left(\mathrm{SO}_{4}{ }^{2-}\right)$, and chloride $\left(\mathrm{Cl}^{-}\right)$concentrations were analysed by ion chromatography.

To estimate the total deposition of nitrogen, we used the canopy budget model developed by Ulrich (1983), extended by Draaijers and Erisman (1995), and synthesized by de Vries et al. (2001). In this model, throughfall fluxes represent total deposition plus or minus canopy exchanges (leaching or uptake). Sodium is assumed to interact little with the canopy and is used as a tracer for estimating the dry deposition of base cations. Other assumptions in the model relate to the relative exchange capacities of protons, ammonium, and nitrate. In our calculations, the (estimated) leaching of weak acids was also taken into account. All equations are given in Thimonier et al. (2005).

At the sites of Lens and Isone, where throughfall was not measured, an estimate of the total deposition was obtained from the model developed for Switzerland (Rihm 1996; Rihm and Kurz 2001). As the modelled total deposition of nitrogen was found to be systematically higher than the total deposition derived from throughfall measurements (Thimonier et al. 2005), we corrected the deposition modelled for Lens and Isone. The correction factor that we applied was the ratio between (1) the total deposition derived from throughfall and (2) the modelled total deposition, calculated at a site located in the same region and with a similar stand composition. Novaggio was 
the site used for Isone, as both are broadleaved stands in the Southern Alps, and Visp for Lens, as both are sites in the Alps in Valais, with Pinus sylvestris as the main species. At the Chironico site, throughfall measurements were stopped during winter. The missing winter throughfall fluxes of $\mathrm{N}$ were estimated using linear regressions of summer throughfall against summer bulk deposition (Thimonier et al. 2005). The total deposition was set to the value obtained with the Swiss model, which generates deposition estimates that are close to the estimates obtained with the canopy budget model for the southern part of Switzerland (Thimonier et al. 2005).

The critical loads of nutrient nitrogen were calculated for each LWF site with the steady state mass balance (SMB) approach as described by Rihm (1996) and Thimonier et al. (2005). The basic principle of this method is to identify the long-term average $\mathrm{N}$ sources and sinks, and to determine the maximum tolerable $\mathrm{N}$ input (=critical load) that will keep $\mathrm{NO}_{3}{ }^{-}$leaching rates below pre-defined, acceptable values (2-4 $\mathrm{kg} \mathrm{ha}^{-1} \mathrm{a}^{-1}$ depending on the ecosystem). The total deposition of nitrogen was also compared to the empirical critical loads, which range from 10 to $20 \mathrm{~kg} \mathrm{ha}^{-1} \mathrm{a}^{-1}$ for forest ecosystems (Achermann and Bobbink 2003).

\section{Nitrate leaching}

The soil solution was sampled on 8 LWF sites during the period 1999-2003. Ceramic suction cups were set at a depth of $80 \mathrm{~cm}$ at 8 sampling points distributed systematically over the $43 \times 43 \mathrm{~m}$ intensive monitoring subplot, on which 8 of the 16 throughfall collectors were also installed. At the beginning of each sampling period, a vacuum of $500 \mathrm{hPa}$ was applied to the suction cups. The samples were taken every 2 weeks, together with the precipitation samples (Graf Pannatier et al. 2004). The values for one additional site (Alptal) were measured as runoff from a small experimental catchment close to the LWF site (Schleppi et al. 2004). The soil solution or runoff samples were analysed in the laboratory using the same analytical methods as those used for the precipitation samples.

Water fluxes were calculated with a monthly waterbalance model (WATBAL, Starr 1999). WATBAL is a storage model where precipitation (plus any snowmelt) equals the sum of evapotranspiration, soil-water drainage and changes in soil-water storage. It assumes free drainage and is driven by readily available meteorological data (including air temperature, precipitation, cloudiness, and wind speed) and a limited number of site conditions (latitude, elevation, forest-canopy-cover fraction, water content at field capacity, and the permanent wilting point for the soil layer of interest). It has been used in several forested sites throughout Europe (e.g. Forsius et al. 2005; Laubhann et al. 2009; Solberg et al. 2009). Soil water contents at field capacity and at the permanent wilting point were derived from pedo-transfer functions (Arbeitskreis Standortskartierung 1996) using soil texture, bulk density, and organic matter content (Walthert et al. 2003). The measurements of the soil matric potential or the water content were used to check the plausibility of the model results. Nitrate leaching was calculated by multiplying the $\mathrm{NO}_{3}{ }^{-}$concentrations in the soil solution at a depth of $80 \mathrm{~cm}$ with the modelled water flux, except at Alptal, where the measured discharge was used instead (Schleppi et al. 2004).

For the nitrogen budget calculations (input-output), we worked on a subset of deposition data, using only the measurement years for which nitrate leaching data were also available, i.e. before 01/01/2004 (see Table 1).

\section{Nutrient status of the forest trees}

The mineral nutrition of the forest trees was assessed through foliar analyses. Five to six trees of the main species were selected outside the plot in the surrounding buffer zone, where the site and management conditions are comparable to those on the plot itself. The selected trees belonged to the dominant or predominant classes and were representative of the typical defoliation level of the plot (Stefan et al. 2000). Foliage was harvested by climbing up the tree with a ladder or a throw line, and using a pruning pole. Samples were taken in the upper third of the crown (between the 7th and 15 th whorl for conifers) every 2 years (Table 1), in summer (broadleaved trees) or autumn (coniferous trees).

Leaves and current year needles were oven-dried at $65^{\circ} \mathrm{C}$ to constant weight, ground, and then analysed in the laboratory. The total carbon $(\mathrm{C})$ and total nitrogen $(\mathrm{N})$ were analysed with a $\mathrm{C}+\mathrm{N}$ element analyzer. Sulphur (S), phosphorus $(\mathrm{P})$, potassium $(\mathrm{K})$, calcium $(\mathrm{Ca})$, and magnesium $(\mathrm{Mg})$ were determined by microwave digestion with $\mathrm{HNO}_{3}$, followed by analysis with ICP-AES.

The foliar concentrations were compared with optimal and critical ranges of foliar concentrations taken from the literature (Bergmann 1993; Hüttl 1990; Van den Burg 1990). As these reference values may not be appropriate for our sites located at high elevations, we will give more weight to the relative differences between the foliar concentrations for a given tree species across our sites.

\section{Crown defoliation}

Crown defoliation was assessed within the tree condition inventory (Sanasilva, described by e.g. Brang 1998; Dobbertin et al. 2001). Although the term 'defoliation' is misleading because the actual loss of foliage is not assessed, we will keep this term as it has been used internationally (see Dobbertin 2005). In Switzerland, total defoliation was assessed visually as the percent defoliation of a tree 
compared with a reference tree of the same species and age growing at the same site with maximum foliage $(0 \%$ defoliation) using reference photographs (Müller and Stierlin 1990). The percentage of this defoliation that could not be attributed to a known cause by the field crew was defined as the unexplained defoliation. Unexplained defoliation, i.e. defoliation without obvious (at the time of the assessment) biotic or abiotic causes, such as insect-caused defoliation or frost damage, is more likely than total defoliation to relate to atmospheric deposition or the nutrient status of trees. Therefore, we used unexplained defoliation in our analysis.

The Sanasilva inventory was carried out every year on all trees with a diameter at breast height $\geq 12 \mathrm{~cm}$, either within one or two subplots of $2,500 \mathrm{~m}^{2}$, or within the whole plot ( 2 ha as a rule), depending on the site and the year. For comparability purposes, the mean defoliation per site and year was calculated using the trees present in the subplot(s) only, even if the whole plot had been surveyed. Defoliation (total and unexplained) was also assessed on the five trees sampled for foliar analyses in the years when foliage was harvested.

\section{Environmental factors}

$\mathrm{NO}_{3}{ }^{-}$leaching, foliar concentrations, and crown defoliation were related to several other environmental factors in addition to $\mathrm{N}$ deposition. The chemistry of the soil matrix was determined once during the period 1994-1999 at all sites apart from Davos. The chemical data were obtained from soil profiles as well as from 16 sampling points systematically distributed in the $43 \times 43 \mathrm{~m}$ intensive monitoring subplot (Walthert et al. 2003). The variables selected as predictors were the $\mathrm{C} / \mathrm{N}$ and $\mathrm{C} / \mathrm{P}$ ratios of the forest floor (Oe and Oa layers) or, when these organic horizons were missing because the forest floor was a mull type (Oi layer), in the upper $5 \mathrm{~cm}$ of the mineral soil; the pools of organic $\mathrm{C}$, total $\mathrm{N}$, exchangeable $\mathrm{Ca}, \mathrm{Mg}$, and $\mathrm{K}\left(\mathrm{NH}_{4} \mathrm{Cl}\right.$ extraction) down to a depth of 40 and $60 \mathrm{~cm}$; and the $\mathrm{pH}$, base saturation, and contents of exchangeable $\mathrm{Ca}, \mathrm{Mg}$, and $\mathrm{K}$ in the $0-5 \mathrm{~cm}$ layer and the $0-40 \mathrm{~cm}$ layer.

The floristic composition of the ground vegetation, which was recorded several times at 16 sites (all except Davos) during the period 1994-2003, was used to calculate mean Landolt's indicator values (Landolt 1977). Landolt's values express the ecological behaviour of particular Swiss flora in relation to such environmental factors as soil nitrogen availability, soil $\mathrm{pH}$, light, temperature, soil moisture, humus content, and continentality. Averaging Landolt's values for all species occurring at a site provides a synthetic index of the conditions for each of these environmental factors.

The climatic and physical factors taken into account included the altitude of the site, the long-term mean annual precipitation and annual temperature, as well as a drought index defined as the average of the ratios between actual and potential evapotranspiration (AET/PET) for the years 1998-2003. These ratios were calculated for the period March to August using the WATBAL model (see above).

\section{Statistical analyses}

The factors explaining the variation in foliar nitrogen concentrations and crown defoliation (mean values for all measurement years) were explored with an analysis of covariance using the GLM procedure (SAS Institute Inc. 2002-2005). In this analysis, the species factor was classified into the five classes used in the ICP-Forests report on the condition of the foliage in European forests (Stefan et al. 1997), namely Pinus sp. (Pinus sylvestris, Pinus mugo and Pinus cembra), Picea abies, Abies alba, Fagus sylvatica, and Quercus sp. (Quercus robur, Quercus cerris).

\section{Results}

Nitrogen deposition

The total nitrogen deposition in the Alps was rather low (ranging from $2.4 \mathrm{~kg} \mathrm{ha}^{-1} \mathrm{a}^{-1}$ at Celerina to $8 \mathrm{~kg} \mathrm{ha}^{-1} \mathrm{a}^{-1}$ at Visp, on average) and below the critical loads (Fig. 2). Deposition was highest (31 kg ha $\mathrm{kg}^{-1}$ on average) in the southern part of Switzerland, at the Novaggio site, which is subjected to the emissions of the industrialized and densely populated Po Basin. It was also high at Schänis (26 $\mathrm{kg} \mathrm{ha}^{-1} \mathrm{a}^{-1}$ on average), which is located on the northern flank of the Alps at the transition between the Swiss Plateau and the Pre-Alps. At these two sites, deposition largely exceeded the SMB and empirical critical loads. At all other sites apart from Jussy (Swiss Plateau), deposition was within the empirical range of critical loads. Nitrogen deposition was close to the SMB critical loads or even above them, in particular for the unmanaged stands, for which the SMB critical loads are lower (Neunkirch, Bettlachstock).

Nitrate leaching

Measurable $\mathrm{NO}_{3}{ }^{-}$leaching was observed only at sites where the throughfall fluxes exceeded $10 \mathrm{~kg} \mathrm{~N} \mathrm{ha}^{-1} \mathrm{a}^{-1}$. Not all of these sites, however, had significant $\mathrm{NO}_{3}{ }^{-}$leaching rates (Fig. 3). The highest $\mathrm{NO}_{3}{ }^{-}$leaching rates were recorded at Othmarsingen $\left(15.7 \mathrm{~kg} \mathrm{~N} \mathrm{ha}^{-1}\right.$ in 1999) and at Schänis (12.4 $\mathrm{kg} \mathrm{N} \mathrm{ha}^{-1} \mathrm{a}^{-1}$, on average, with a peak of $20.4 \mathrm{~kg} \mathrm{~N} \mathrm{ha}^{-1}$ in 2002), which received $\mathrm{N}$ deposition that largely exceeded the critical loads. No or little nitrate leaching was measured at Vordemwald, Beatenberg, Celerina, and Novaggio, independently of whether the 
Fig. 2 Total nitrogen deposition (mean value for all available years and standard deviation) and critical loads at LWF sites. The total nitrogen deposition was derived from throughfall using the canopy budget model, except where throughfall measurements were not available (LEN, ISO) or incomplete (CHI; see text). Critical loads for nutrient $\mathrm{N}$ were calculated with the steady state mass balance method (thick line). Empirical critical loads range from 10 to $20 \mathrm{~kg} \mathrm{ha}^{-1} \mathrm{a}^{-1}$ (shaded area)

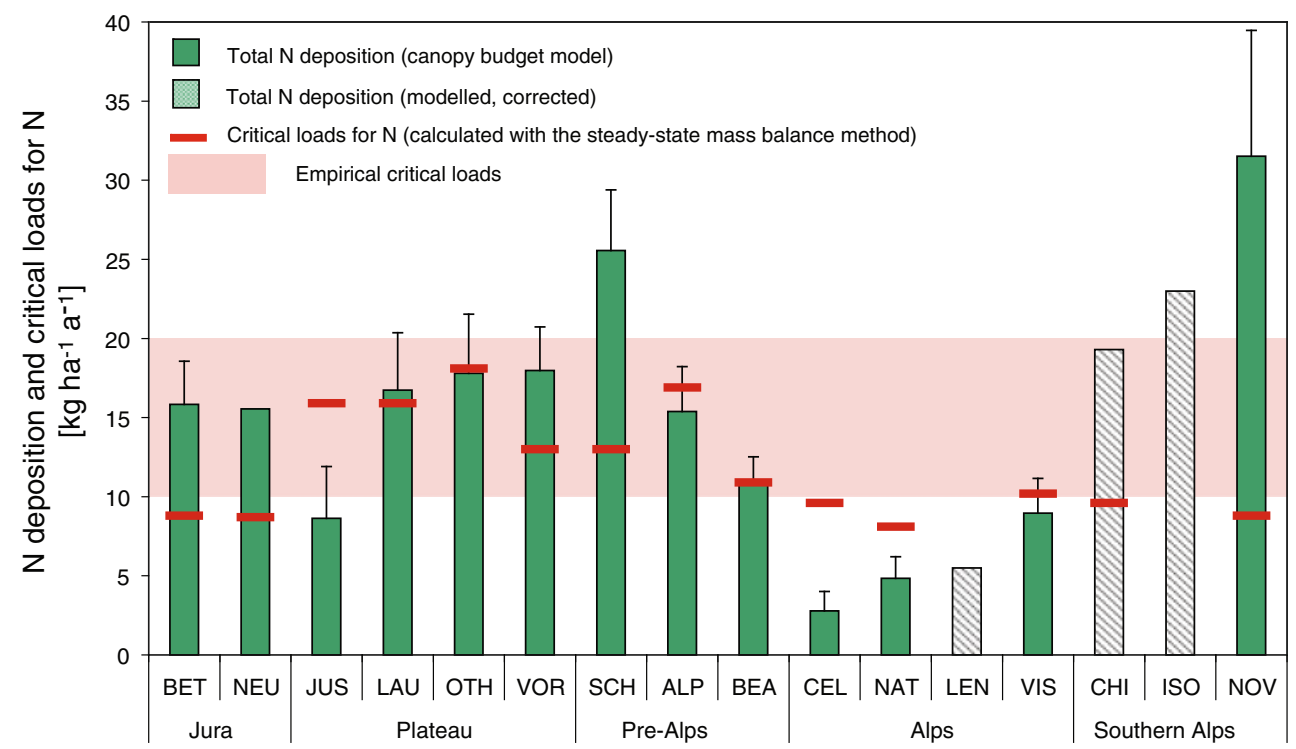

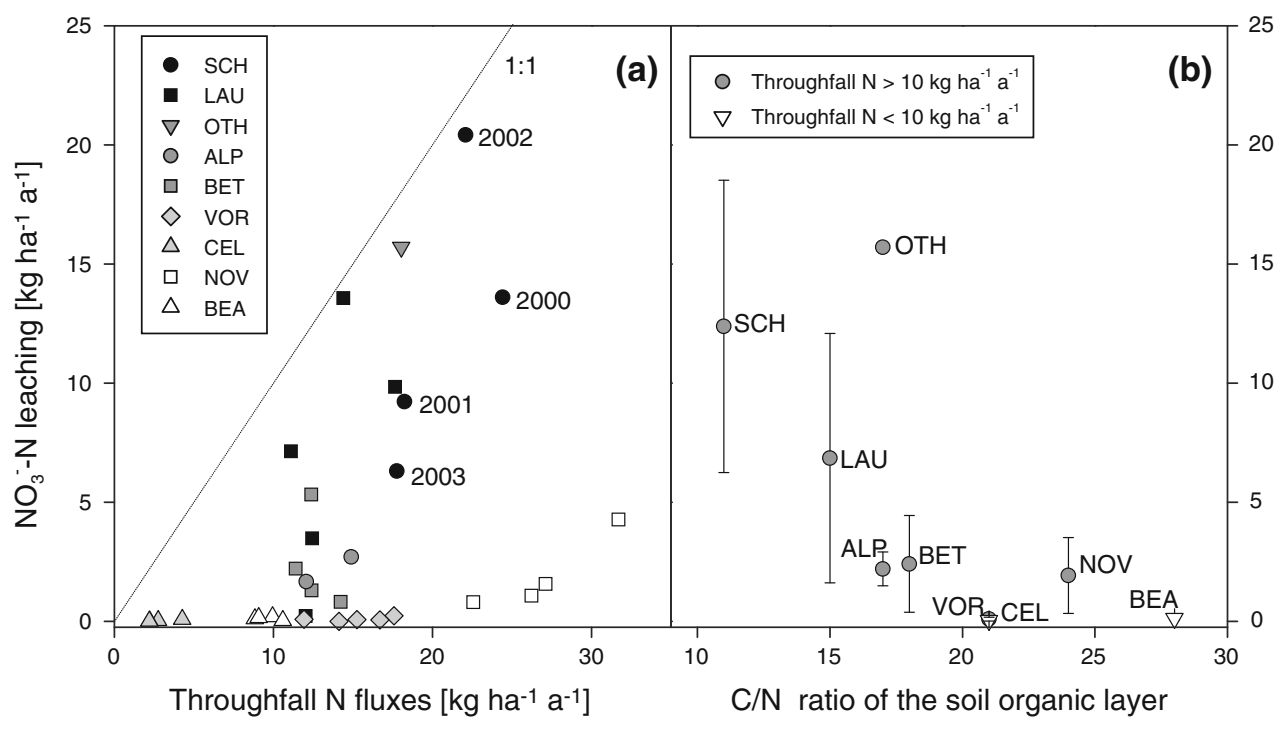

Fig. 3 a Relationship between leaching fluxes of $\mathrm{NO}_{3}{ }^{-}$from the root zone and throughfall deposition of $\mathrm{N}$. Annual values for each site are shown. b Relationship between mean $\mathrm{NO}_{3}{ }^{-}$leaching and the $\mathrm{C} / \mathrm{N}$

ratio of the soil organic layer, or, when it was not present, of the upper $5 \mathrm{~cm}$ of the mineral soil

critical loads were exceeded or not. Nitrate leaching at Novaggio was only $1.9 \mathrm{~kg} \mathrm{~N} \mathrm{ha}^{-1} \mathrm{a}^{-1}$, on average, for the period 2000-2003, even though the total deposition of $\mathrm{N}$ exceeded the critical loads by about $25 \mathrm{~kg} \mathrm{ha}^{-1} \mathrm{a}^{-1}$.

Since the soil solution at a depth of $80 \mathrm{~cm}$ contained only $\mathrm{NO}_{3}{ }^{-}$and no detectable $\mathrm{NH}_{4}{ }^{+}, \mathrm{NO}_{3}{ }^{-}$leaching approximated $\mathrm{N}$ leaching. The $\mathrm{N}$ input was larger than the $\mathrm{N}$ output at all the sites investigated (Fig. 3a). At the site level, there was a weak relationship between the annual throughfall fluxes of $\mathrm{N}$ and $\mathrm{NO}_{3}{ }^{-}$leaching: higher $\mathrm{NO}_{3}{ }^{-}$ leaching was usually associated with higher throughfall fluxes of $\mathrm{N}$.
The $\mathrm{C} / \mathrm{N}$ ratio of the forest soil appeared to be a critical factor regarding nitrogen leaching. No or almost no nitrate leaching was recorded for $\mathrm{C} / \mathrm{N}$ ratios $\geq 21$, even at sites with high or moderate $\mathrm{N}$ deposition (Novaggio and Vordemwald; Fig. 3b).

\section{Foliar nitrogen concentrations}

In several of the coniferous stands, the foliar $\mathrm{N}$ concentrations were below the optimum ranges mentioned in the literature (Fig. 4). In contrast, for broadleaved stands, concentrations were within or even above the optimum 


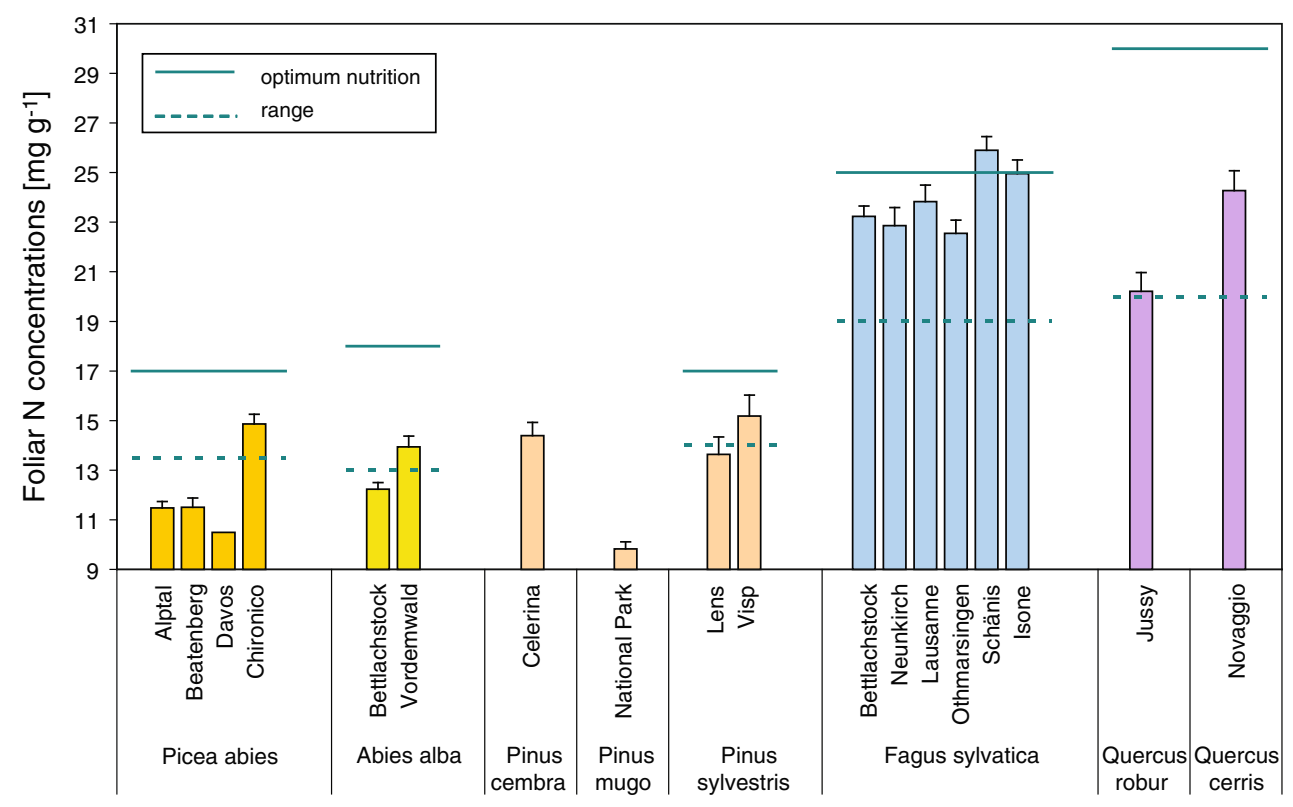

Fig. $4 \mathrm{~N}$ concentrations (mean value for all available years and standard error) in the foliage of the main coniferous and broadleaved species at the LWF sites. The plain and dashed lines delimit the range within which foliar concentrations indicate an adequate mineral nutrition according to Bergmann (1993)

environmental variables significantly improved the model either.

\section{Unexplained crown defoliation}

The average crown defoliation was greater in the conifer stands than in the broadleaved stands (Fig. 7). The variability in crown defoliation was also higher across the coniferous stands than across the broadleaved stands. Compared with the defoliation assessed on the subplots, lower defoliation levels were assessed on the 5 trees sampled for foliar analyses at Visp (20\% on average for the 5 trees vs. $39 \%$ on the plot scale) and in the National Park (30 vs. 52\%), while the defoliation of sample trees was higher than average at Alptal (37 vs. 13\%; see Table 4). In the National Park, many average trees are severely defoliated, and trees with crowns in better condition were intentionally selected for the foliar analyses. At the Visp site, some of the trees sampled for foliar analyses died and had to be replaced with new trees, which artificially decreased the average defoliation of the sampled trees. On the other hand, the spruce stand at Alptal is managed as a selection forest, with only a few large old trees in the dominant or predominant layers where trees were selected for foliage sampling. As older spruce trees tend to be more defoliated than younger trees, the average defoliation of the sample trees is higher than the average defoliation at the plot level.

We found no significant correlation between unexplained crown defoliation and $\mathrm{N}$ deposition. For conifers, unexplained crown defoliation was negatively correlated 

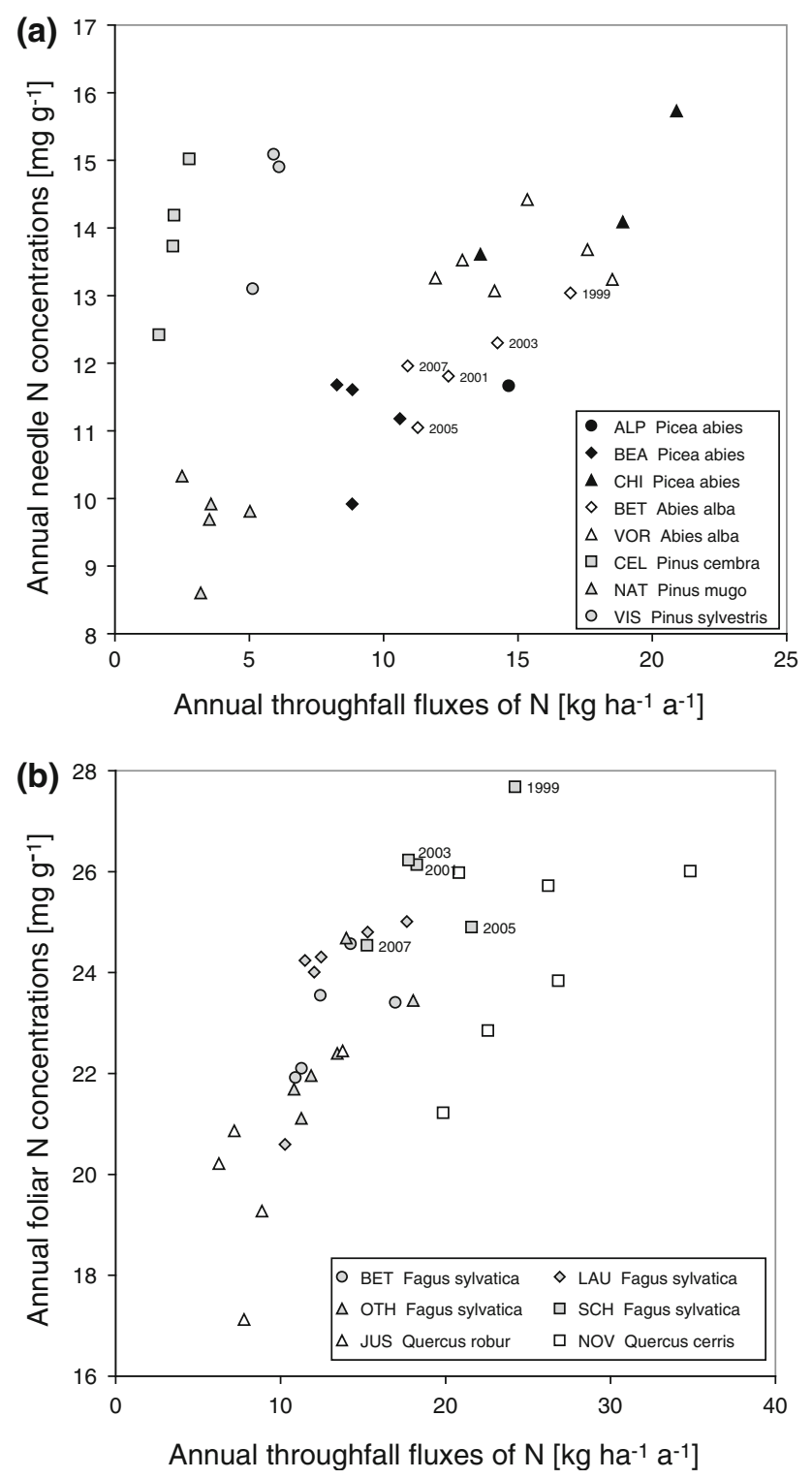

Fig. 5 Relationship between foliar N concentrations and throughfall deposition of $\mathrm{N}$ in coniferous stands (a) and broadleaved stands (b). Annual values for each site are shown. As an example, sampling years are indicated for the Bettlachstock (a) and Schänis (b) sites

with foliar $\mathrm{N}$ concentrations (Fig. 8). The relationship was stronger when the crown defoliation variable stemmed from the five trees sampled for foliar analyses rather than from the trees present within the $2,500 \mathrm{~m}^{2}$ subplot(s). Here again, there also seemed to be a relationship at the site level across the measurements years. Unexplained crown defoliation tended to be higher for trees with foliar $\mathrm{N}$ concentrations in the deficiency range (Fig. 8). For broadleaved species, we found no relationship between defoliation and foliar concentrations.

The relationship between crown defoliation and foliar $\mathrm{N}$ concentrations was confirmed by the analysis of covariance run on the mean crown defoliation per site. The species factor explained the greatest part of the variation. The second best independent variable explaining the variation in crown defoliation was the foliar $\mathrm{N}$ concentration, followed by the foliar P concentration (Table 3; Fig. 9).

\section{Overview}

Table 4 summarizes for each site the mean values of the measured parameters. High $\mathrm{N}$ deposition levels, exceeding the critical loads for nitrogen, do not necessarily lead to nitrate leaching, as illustrated by the examples of Novaggio and Schänis: the onset of significant leaching on an annual basis is driven by the soil $\mathrm{N}$ status (as indicated by the $\mathrm{C} / \mathrm{N}$ ratio of the forest floor and the humus type). High $\mathrm{N}$ deposition is associated with high foliar $\mathrm{N}$ concentrations at both sites; however, the foliar N/P ratio (Table 4) indicates a balanced nutrition at Schänis, while the N/P ratio is unfavourably high at Novaggio. The two sites also differ in the crown condition of the trees, with higher unexplained defoliation assessed at Novaggio than at Schänis.

\section{Discussion}

Nitrate leaching

Nitrate leaching at our sites was low to moderate $(0-16 \mathrm{~kg}$ $\mathrm{N} \mathrm{ha}^{-1} \mathrm{a}^{-1}$ ) and within the range of values reported by de Vries et al. (2007) from 121 other ICP-Forests level II sites across Europe (119 sites between 0 and $20 \mathrm{~kg} \mathrm{~N} \mathrm{ha}^{-1} \mathrm{a}^{-1}$ and two sites between 20 and $50 \mathrm{~kg} \mathrm{~N} \mathrm{ha}^{-1} \mathrm{a}^{-1}$ ). MacDonald et al. (2002) also reported nitrate leaching values ranging from $<1$ to $>40 \mathrm{~kg} \mathrm{~N} \mathrm{ha}^{-1} \mathrm{a}^{-1}$, using a set of 181 European sites. Nitrate leaching above $5 \mathrm{~kg} \mathrm{~N} \mathrm{ha}^{-1} \mathrm{a}^{-1}$ was systematically associated with nitrate concentrations $>1 \mathrm{mg} \mathrm{N}^{-1}$ at our sites, confirming the value of this concentration threshold as an indicator of enhanced $\mathrm{N}$ losses through leaching (Table 4; Dise and Wright 1995; Gundersen 1995).

The input-output budget indicates that no site released more $\mathrm{N}$ than it received and that $\mathrm{N}\left(3-33 \mathrm{~kg} \mathrm{ha}^{-1} \mathrm{a}^{-1}\right)$ was retained in the ecosystem or denitrified. Denitrification losses are, nevertheless, most probably small in proportion, as indicated by measurements at Alptal. At this site, the wet soil conditions led us to expect it to have the highest denitrification fluxes of all sites. Annual gaseous $\mathrm{N}$ losses of $1.7 \mathrm{~kg} \mathrm{ha}^{-1}$ were measured, corresponding to $10 \%$ of the throughfall or total $\mathrm{N}$ deposition (Mohn et al. 2000). On other sites, denitrification is likely to be lower and generally negligible. The amounts of $\mathrm{N}$ retained are comparable to those assessed in $80 \%$ of the 121 level II sites (2-25 $\mathrm{kg} \mathrm{N} \mathrm{ha}^{-1} \mathrm{a}^{-1}$ ) across Europe (de Vries et al. 2007). 
Table 2 Results of the analysis of covariance run on the foliar $\mathrm{N}$ concentration $\left(\mathrm{mg} \mathrm{g}^{-1}\right)$ of the main tree species averaged over the whole measuring period (see Table 1)

\begin{tabular}{|c|c|c|c|c|c|c|c|}
\hline Source & $\begin{array}{l}\text { Degrees of } \\
\text { freedom }\end{array}$ & $\begin{array}{l}\text { Sum of } \\
\text { squares }\end{array}$ & $\begin{array}{l}\text { Mean } \\
\text { square }\end{array}$ & $F$ & $P(f>F)$ & $\begin{array}{l}\text { Parameter } \\
\text { estimate }\end{array}$ & $\begin{array}{l}\text { Standarc } \\
\text { error }\end{array}$ \\
\hline Species & 4 & 277.1 & 69.3 & 35.7 & $<0.0001$ & & \\
\hline Picea abies & & & & & & 12.62 & $0.80^{\mathrm{a}}$ \\
\hline Abies alba & & & & & & 12.70 & $0.99^{\mathrm{a}}$ \\
\hline Pinus sp. & & & & & & 15.42 & $0.95^{\mathrm{a}}$ \\
\hline Quercus sp. & & & & & & 21.14 & $1.04^{\mathrm{b}}$ \\
\hline Fagus sylvatica & & & & & & 22.94 & $0.64^{\mathrm{b}}$ \\
\hline TDN & 1 & 21.3 & 21.3 & 11.0 & 0.007 & 0.22 & 0.07 \\
\hline Model & 5 & 490.2 & 98.0 & 50.5 & $<0.0001$ & & \\
\hline Error & 11 & 21.3 & 1.9 & & & & \\
\hline Corrected total & 16 & 511.6 & & & & & \\
\hline
\end{tabular}

'TDN' is the average total deposition of nitrogen (in $\mathrm{kg} \mathrm{ha}^{-1} \mathrm{a}^{-1}$ ). 'Species' refers to the effect of the main tree species or genera given as leastsquare means. Different letters denote significant differences according to the Bonferroni test at the $P=0.05$ level

Mean $=17.9 ; R^{2}=0.96 ;$ Root mean square error $=1.39$

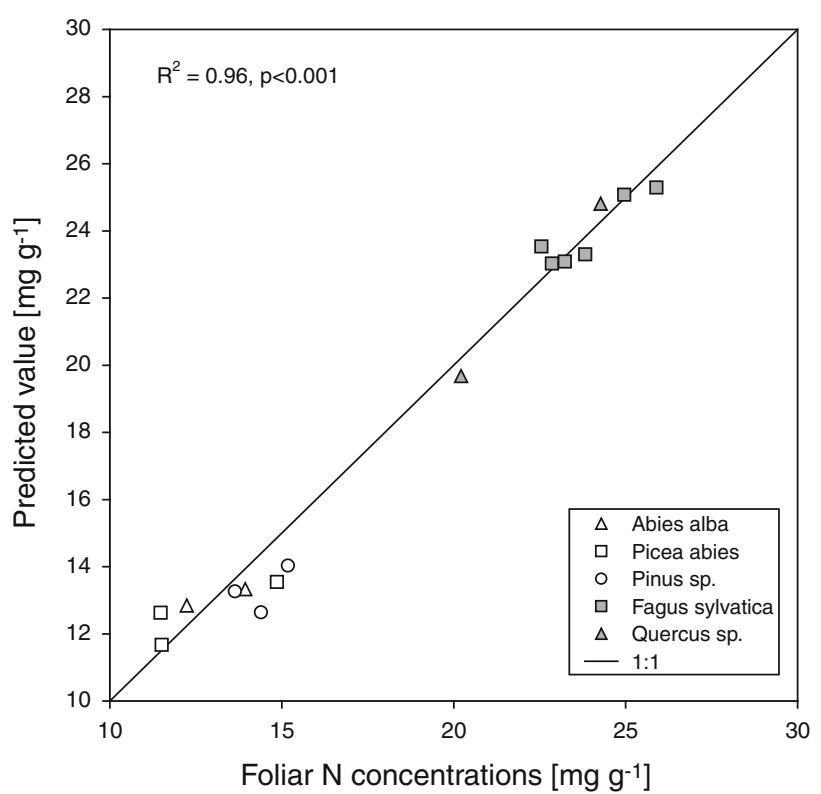

Fig. 6 Foliar $\mathrm{N}$ concentrations: predicted versus measured. Foliar $\mathrm{N}$ concentration is a linear function of the tree species and total $\mathrm{N}$ deposition

The relationship between throughfall fluxes of $\mathrm{N}$ and $\mathrm{NO}_{3}{ }^{-}$leaching was rather weak, both on comparing the sites and, when annual values were considered, at the site level. At the site level, annual $\mathrm{NO}_{3}{ }^{-}$leaching rates can be expected to depend not only on the overall annual $\mathrm{N}$ deposition but also on the precipitation regime (distribution over time and intensity), as well as other factors, such as temperature and soil moisture, that influence soil $\mathrm{N}$ transformation processes (e.g. Vervaet et al. 2002). Across our sites, the relationship between $\mathrm{N}$ leaching and $\mathrm{N}$ deposition cannot be statistically tested because our sample set is too small. The influence of the tree species cannot be identified since the sites with beech, for example, were located in regions with higher $\mathrm{N}$ deposition, whereas those with spruce and pine forests were in areas with lower $\mathrm{N}$ deposition. However, our results confirm that, at deposition levels above $10 \mathrm{~kg} \mathrm{~N} \mathrm{ha}^{-1} \mathrm{a}^{-1}, \mathrm{NO}_{3}^{-}$, leaching is influenced by the $\mathrm{C} / \mathrm{N}$ ratio of the forest floor, as also found by e.g. Gundersen et al. (1998a), Dise et al. (1998), MacDonald et al. (2002), de Vries et al. (2007) and Dise et al. (2009). These authors showed that $\mathrm{N}$ leaching could be predicted by combining $\mathrm{N}$ deposition and the $\mathrm{C} / \mathrm{N}$ ratio of the forest floor, either as input variables in regression equations or as stratification variables. In particular, the relationship between $\mathrm{N}$ deposition and $\mathrm{N}$ leaching was found to be stronger when the data were stratified into categories of $\mathrm{C} / \mathrm{N}$ less than or greater than $23-25$. The $\mathrm{C} / \mathrm{N}$ ratios at the LWF sites with the highest $\mathrm{N}$ deposition clearly show that the presence of an Oe layer, characterized by $\mathrm{C} / \mathrm{N}$ ratios $\geq 21$, decreased nitrate leaching (Vordemwald, Novaggio), while mull-type forest floors (Lausanne, Othmarsingen, Schänis), characterized by $\mathrm{C} / \mathrm{N}$ ratios $\leq 21$, were prone to nitrate leaching. Borken and Matzner (2004) pointed out that the stock and the quality of soil organic matter might be a key factor in retaining inorganic nitrogen through abiotic or biotic immobilization. The organic $\mathrm{C}$ stock in the soil $(0-60 \mathrm{~cm})$ in Novaggio $\left(174,000 \mathrm{~kg} \mathrm{C} \mathrm{C}_{\text {or- }}\right.$ $\left.\mathrm{g} \mathrm{ha}^{-1}\right)$ and in Alptal $\left(196,000 \mathrm{~kg} \mathrm{C}_{\text {org }} \mathrm{ha}^{-1}\right)$ is much larger than the $\mathrm{C}_{\text {org }}$ stock at other sites $(51,000$ $145,000 \mathrm{~kg} \mathrm{C}_{\text {org }} \mathrm{ha}^{-1}$ ) (Walthert et al. 2003). This may explain the large capacity (about $30 \mathrm{~kg} \mathrm{ha}^{-1} \mathrm{a}^{-1}$ in Novaggio) of the soil to retain the high atmospheric input of nitrogen. In Alptal, nitrogen tracer studies $\left({ }^{15} \mathrm{NO}_{3}{ }^{-}\right.$and ${ }^{15} \mathrm{NH}_{4}{ }^{+}$) have shown that deposited $\mathrm{N}$ has accumulated in the soil organic matter (Providoli et al. 2005, 2006). 


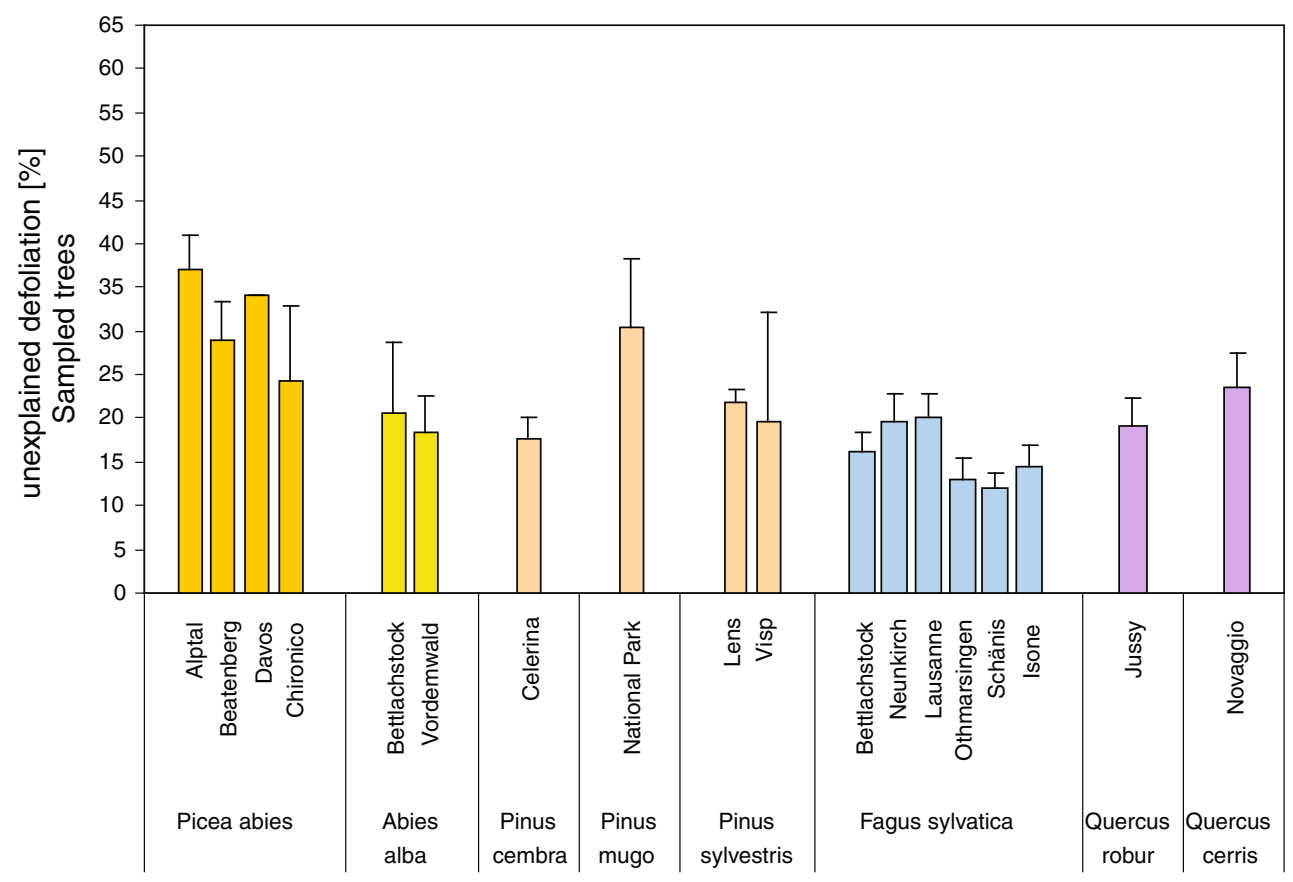

Fig. 7 Average unexplained defoliation assessed on the trees sampled for foliar analyses

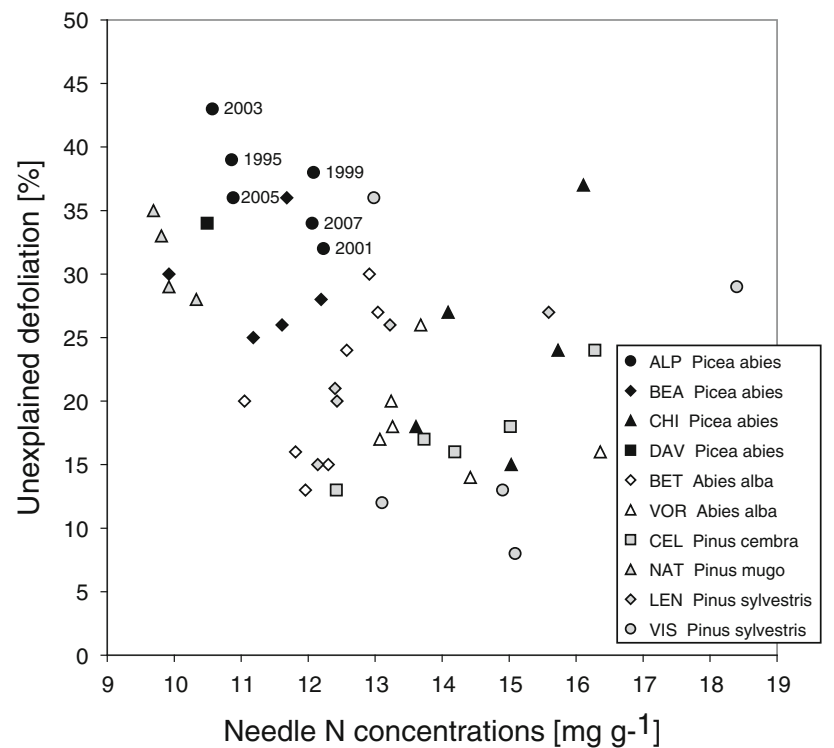

Fig. 8 Relationship between the unexplained defoliation assessed on the trees sampled for foliage analysis and the foliar $\mathrm{N}$ concentrations in coniferous stands. Annual values for each site are shown. As an example, the measurement years are indicated for the Alptal site

\section{Foliar N concentrations}

A relationship between foliar $\mathrm{N}$ concentrations and $\mathrm{N}$ deposition was apparent in both our coniferous stands and our broadleaved stands. This relationship is consistent with the results of other studies for conifers. Flückiger and Braun (1998) found a strong correlation between needle $\mathrm{N}$ concentrations and modelled $\mathrm{N}$ deposition $(20$ to $>50 \mathrm{~kg}$ $\mathrm{ha}^{-1} \mathrm{a}^{-1}$ ) in the Norway spruce stands of their permanent observation network across Switzerland. Kristensen et al. (2004) also observed a correlation between needle $\mathrm{N}$ concentrations and throughfall fluxes of $\mathrm{N}$, using data from 73 coniferous stands across Europe. At 12 EXMAN and NITREX sites distributed over a wide gradient of $\mathrm{N}$ deposition (from $<10 \mathrm{~kg} \mathrm{ha}^{-1} \mathrm{a}^{-1}$ to $>60 \mathrm{~kg} \mathrm{ha}^{-1} \mathrm{a}^{-1}$ in throughfall), Tietema and Beier (1995) similarly found that needle $\mathrm{N}$ concentrations correlated with throughfall inputs of $\mathrm{N}$, and especially $\mathrm{NH}_{4}{ }^{+}$. Mellert et al. (2004) observed a gradient in needle $\mathrm{N}$ concentrations for spruce (23 sites) and Scots pine (28 sites) from lower $\mathrm{N}$ deposition and $\mathrm{N}$ status in Northern Europe to higher values in Central Europe. Over a much smaller range of deposition (5-11 kg N ha ${ }^{-1} \mathrm{a}^{-1}$ ), Boggs et al. (2007) reported lower $\mathrm{N}$ concentrations in red spruce needles at the site subjected to the lowest deposition level.

Studies in broadleaved stands have produced more varied results. Flückiger et al. (1997), in the beech plots of their permanent observation network, did not observe a similar correlation between foliar $\mathrm{N}$ concentrations and deposition to that found for spruce. Kristensen et al. (2004) also found no relationship between $\mathrm{N}$ deposition and foliar $\mathrm{N}$ concentrations in broadleaves. These authors hypothesized that the lack of relationship could be ascribed to a higher retranslocation of $\mathrm{N}$ prior to senescence in broadleaves compared to conifers, or to the fact that broadleaves are generally found on more fertile soils. Both hypotheses imply that broadleaf foliage would be more independent of 
Table 3 Results of the analysis of covariance run on the unexplained defoliation (\%) averaged over the whole measuring period (see Table 1)

\begin{tabular}{|c|c|c|c|c|c|c|c|}
\hline Source & $\begin{array}{l}\text { Degrees of } \\
\text { freedom }\end{array}$ & $\begin{array}{l}\text { Sum of } \\
\text { squares }\end{array}$ & $\begin{array}{l}\text { Mean } \\
\text { square }\end{array}$ & $F$ & $P(f>F)$ & $\begin{array}{l}\text { Parameter } \\
\text { estimate }\end{array}$ & $\begin{array}{l}\text { Standard } \\
\text { error }\end{array}$ \\
\hline Species & 4 & 277.1 & 69.3 & 5.53 & 0.0109 & & \\
\hline Abies alba & & & & & & 14.12 & $3.18^{\mathrm{a}}$ \\
\hline Pinus sp. & & & & & & 18.58 & $2.82^{\mathrm{ab}}$ \\
\hline Fagus sylvatica & & & & & & 22.44 & $3.54^{\mathrm{ab}}$ \\
\hline Quercus sp. & & & & & & 24.05 & $3.62^{\mathrm{ab}}$ \\
\hline Picea abies & & & & & & 26.23 & $3.35^{\mathrm{b}}$ \\
\hline Foliar N & 1 & 55.4 & 55.4 & 5.14 & 0.0446 & -1.13 & 0.50 \\
\hline Foliar P & 1 & 54.8 & 54.8 & 5.08 & 0.0455 & -8.17 & 3.62 \\
\hline Model & 6 & 715.0 & 119.2 & 11.06 & 0.0004 & & \\
\hline Error & 11 & 118.6 & 10.8 & & & & \\
\hline Corrected total & 17 & 833.6 & & & & & \\
\hline
\end{tabular}

'Foliar N' and 'Foliar P' are the average foliar N and P concentrations, respectively, of the main tree species (in $\mathrm{mg} \mathrm{g}^{-1}$ ). 'Species' refers to the effect of the main tree species or genera given as least-square means. Different letters denote significant differences according to the Bonferroni test at the $P=0.05$ level

Mean $=21.6 ; R^{2}=0.86$; Root mean square error $=3.28$

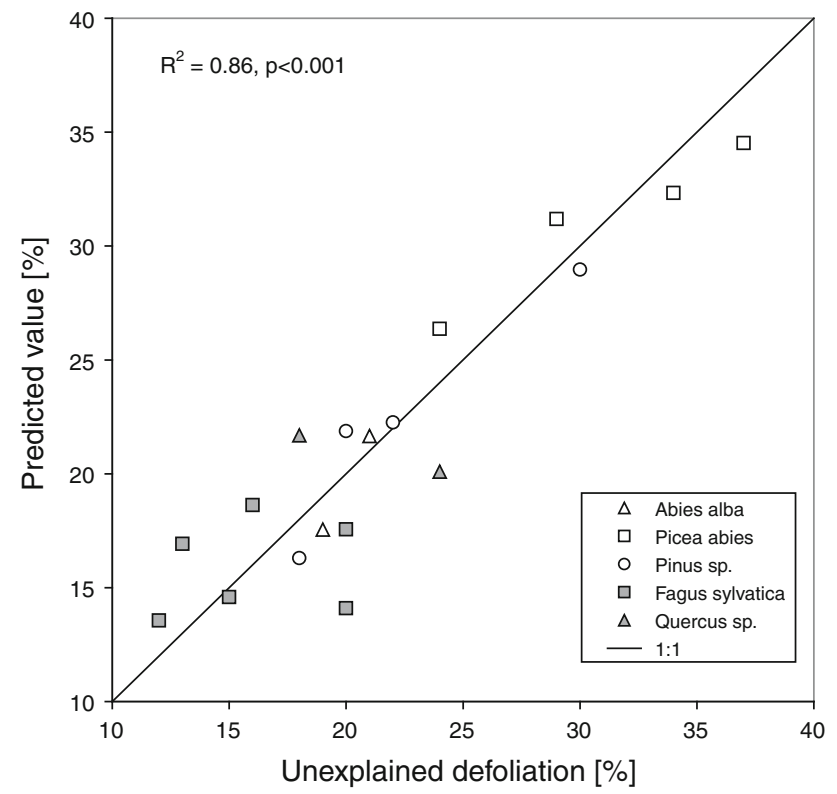

Fig. 9 Unexplained crown defoliation: predicted versus assessed. Crown defoliation is a linear function of the tree species, foliar $\mathrm{N}$ concentration, and foliar P concentrations

$\mathrm{N}$ input. Some other studies, however, have documented a relationship between foliar $\mathrm{N}$ concentrations and deposition for broadleaved species (Boggs et al. 2007; Eichhorn et al. 2001). Eichhorn et al. (2001) found a significant positive correlation between foliar $\mathrm{N}$ concentrations and $\mathrm{NH}_{4}{ }^{+}$ deposition in 23 beech plots of the ICP-Forests level II network. We established a similar relationship between $\mathrm{N}$ deposition and foliar concentrations in our beech stands.

A positive relationship was also apparent for our two oak stands, but this should be considered with caution because the oak species at the two sites are different (Quercus robur at Jussy and Quercus cerris at Novaggio). For oak, little data are available in the literature that would help to check whether the differences between foliar $\mathrm{N}$ concentrations can be ascribed to a species effect rather than to different $\mathrm{N}$ deposition levels. The ICP-Forests report (Stefan et al. 1997) does not distinguish between the different oak species in its European overview. This report does, however, give the minimum, average, and maximum $\mathrm{N}$ concentrations in Quercus cerris foliage for the two countries Italy and Slovakia, where this species was sampled. Compared with the average $\mathrm{N}$ concentrations of $22 \mathrm{mg} \mathrm{g}^{-1}$ (min: 20.3, max: 22.9) recorded in Italy and of $16 \mathrm{mg} \mathrm{g}^{-1}$ (min: 12.8, max: 20.7) in Slovakia, the foliar $\mathrm{N}$ concentrations (average $24.3 \mathrm{mg} \mathrm{g}^{-1}$ ) at Novaggio, the site with the highest deposition levels within our network, are high. Furthermore, the average foliar $\mathrm{N}$ concentrations for Quercus robur given in the ICP-Forests report are either comparable or higher than for Quercus cerris. The fact that this pattern is the opposite of what we found thus supports the hypothesis that the differences in foliar $\mathrm{N}$ concentrations are related to different deposition levels rather than to a species effect.

The analysis of covariance indicates the distinct role of $\mathrm{N}$ deposition, while other factors such as elevation or mean annual temperature do not appear to have a significant effect. The spatial variation in foliar $\mathrm{N}$ concentrations in our stands thus probably cannot be ascribed to differences in the lengths of the growing period between sites, which have been shown to play a role in plant species (Körner 1989; Yin 1992).

At some of our sites, a relationship between deposition and foliar concentrations was also apparent at the site level 


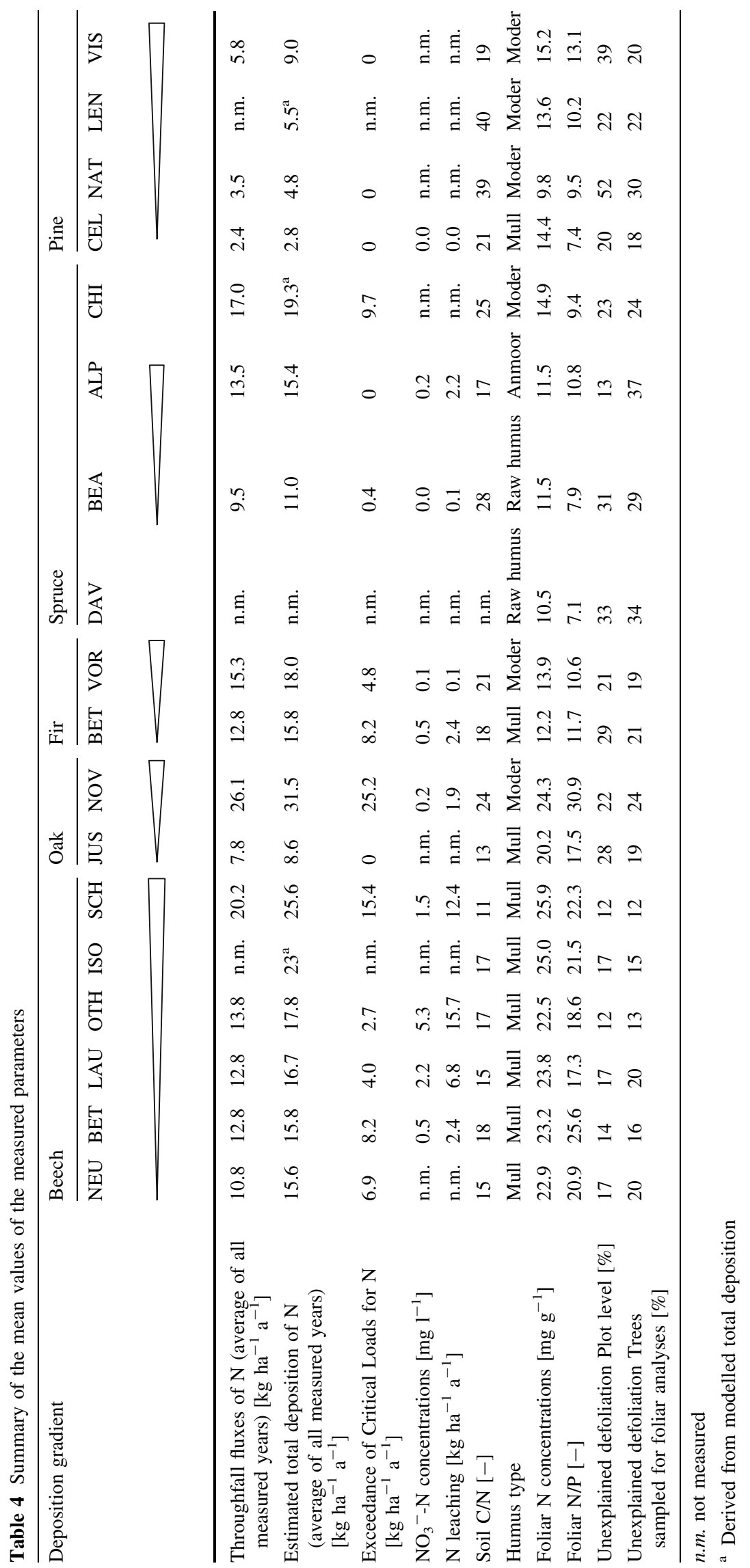


when annual measurements (rather than averages over the whole period) were considered. Fertilization studies provide indications about the extent and pace of change in foliar concentrations following changes in $\mathrm{N}$ inputs. McNulty et al. (2005) showed that low levels of $\mathrm{N}$ fertilization $\left(15.7 \mathrm{~kg} \mathrm{ha}^{-1} \mathrm{a}^{-1}\right.$ added to the ambient bulk deposition of $5.4 \mathrm{~kg} \mathrm{~N} \mathrm{ha}^{-1} \mathrm{a}^{-1}$ ) led to a strong and rapid increase in needle $\mathrm{N}$ concentrations in red spruce, rising from $9 \mathrm{mg} \mathrm{g}^{-1}$ before fertilization to $13.5 \mathrm{mg} \mathrm{g}^{-1} 2$ years later. On the other hand, at NITREX sites where $\mathrm{N}$ was added $\left(+35 \mathrm{~kg} \mathrm{ha}^{-1} \mathrm{a}^{-1}\right)$ to ambient deposition, differences in the needle $\mathrm{N}$ concentrations in the treated plot compared to the control became significant only in the third or fourth year of treatment. Moreover, at one unsaturated site (ambient throughfall of $11 \mathrm{~kg} \mathrm{~N} \mathrm{ha}^{-1} \mathrm{a}^{-1}$ ), no response was observed even after 5 years (Gundersen et al. 1998b). A third possible response was obtained at the $\mathrm{N}$-saturated Höglwald site (Southern Germany), where $\mathrm{N}$ fertilization did not lead to any significant increase in $\mathrm{N}$ concentrations in spruce needles (Huber et al. 2004).

Conversely, decreasing deposition levels can result in decreasing foliar concentrations. After reducing nitrogen deposition from $60 \mathrm{~kg} \mathrm{ha}^{-1} \mathrm{a}^{-1}$ to $<5 \mathrm{~kg} \mathrm{ha}^{-1} \mathrm{a}^{-1}$ by installing a roof, needle $\mathrm{N}$ concentrations in Scots pine (Pinus sylvestris), which were originally $>2 \%$, decreased after 3-4 years compared to the control (Boxman et al. 1998b). In a similar roof experiment in a Norway spruce stand at Solling (Central Germany), reductions in N deposition from about 30 to $10 \mathrm{~kg} \mathrm{ha}^{-1} \mathrm{a}^{-1}$ also led to a lower needle $\mathrm{N}$ concentration than in the control. The difference between control and treated trees was statistically significant after 4 years, but the differences between the means remained rather constant throughout the experiment (Lamersdorf and Borken 2004). On the other hand, in a longterm study in a Scots pine stand, Neirynck et al. (2008) found no decreasing trend in foliar $\mathrm{N}$ concentrations $(>2 \%)$, whereas $\mathrm{N}$ deposition significantly decreased throughout a 16-year period (from $>40 \mathrm{~kg} \mathrm{ha}^{-1} \mathrm{a}^{-1}$ to $>25 \mathrm{~kg}$ $\left.\mathrm{ha}^{-1} \mathrm{a}^{-1}\right)$.

These findings show that the chemistry of the foliage can respond to changes in $\mathrm{N}$ inputs in rather varied ways, depending on the $\mathrm{N}$ status of the site, but that the response is usually delayed and moderate. The delay in the foliage response found at the NITREX sites can be related to the 'cascade of response' to increased nitrogen additions, in which the soil pool acts as a buffer and vegetation effects first appear when the microbial requirement for nitrogen has been met (Kjønaas et al. 1998; Tietema et al. 1995). At Höglwald, the lack of response of needle concentrations to $\mathrm{N}$ fertilization was ascribed to the efficient regulation of $\mathrm{NO}_{3}{ }^{-}$uptake by the roots, which would also explain why foliar $\mathrm{N}$ concentrations indicate an optimal to luxurious nutritional status at this site, but no overfeeding of the trees
(Gessler et al. 1998; Huber et al. 2004). Other mechanisms of regulation, such as the increase in fine root mass, may also be involved in maintaining the $\mathrm{N}$ supply for the trees when, conversely, $\mathrm{N}$ deposition is reduced (Solling roof experiment, Lamersdorf and Borken 2004).

In view of the usually delayed and mostly moderate response of foliar concentrations to changes in $\mathrm{N}$ inputs, the apparent relationship between annual deposition and foliar $\mathrm{N}$ concentrations at the site level is rather surprising. This could be related to decreasing temporal trends in throughfall $\mathrm{N}$ deposition (significant at $P<0.10$ or lower, results not shown, at Lausanne, Othmarsingen, Schänis and Novaggio), in conjunction with decreasing foliar $\mathrm{N}$ concentrations over time. This simultaneous decrease contributes to the apparent relationship at the site level. Smidt (2007) similarly reported decreasing trends for both deposition and foliar concentrations for $\mathrm{N}$ on Austrian sites. It is possible that confounding factors may also be behind this relationship at the site level. For example, $\mathrm{N}$ deposition correlates positively with precipitation volumes, which have been shown to influence foliar N concentrations (e.g. Evers 1972).

\section{Crown defoliation}

\section{Crown defoliation and nutrient status}

Crown defoliation is an indicator of tree vitality that is generally not cause-specific, i.e. the defoliation symptom can arise from several causes (e.g. Dobbertin 2005). In some cases (e.g. insect infestations), the cause of defoliation can be identified in the field, but the assessed defoliation is then included in the explained part of total defoliation by the field crew. Identifying the causes of the unexplained part of defoliation usually requires further intensive investigations, such as those carried out at two of our sites: In the National Park, the cause of high unexplained defoliation of Pinus mugo is assumed to be root rot (Cherubini et al. 2002). At the site in Visp, the high mortality of Pinus sylvestris was found to be related to drought stress (Dobbertin and Rigling 2006). At the other LWF sites, it had not previously been possible to ascribe unexplained defoliation to any known factors.

Our analysis of covariance showed that two factors, in addition to the tree species, explained the variation in crown defoliation across our sites, namely: the foliar $\mathrm{N}$ and $\mathrm{P}$ concentrations. In coniferous species, increasing foliar $\mathrm{N}$ concentrations were related to decreasing unexplained defoliation. In contrast, no relationship was found between crown defoliation and foliar nutrient concentrations for broadleaves. While foliar $\mathrm{N}$ concentrations were below or in the optimal range for conifers, none of the broadleaved trees showed $\mathrm{N}$ concentrations below the optimal range. The lack of correlation between foliar $\mathrm{N}$ concentrations and 
defoliation for broadleaves could also be ascribed to the small variability and the lower levels of crown defoliation in our broadleaved stands compared with the coniferous stands.

A strong negative relationship between needle $\mathrm{N}$ concentrations and needle loss, similar to that in our results, was found in spruce stands in Germany, based on a much larger dataset ( $n=249$ ) from the Bavarian soil inventory (Gulder and Kölbel 1993; Kandler 1994; in Ortloff and Schlaepfer 1996). In the German study, foliar N concentrations ranged from 9 to $\sim 17 \mathrm{mg} \mathrm{g}^{-1}$, i.e. from the deficiency to the optimum range, as was the case for our sampled trees. In another study in the Bavarian Alps, no significant relationships between crown defoliation of Picea abies and the needle concentrations in any single element were found, but deficient concentrations in $\mathrm{P}$ and $\mathrm{N}$ in oneyear-old needles were invariably associated with low needle weights and high defoliation (Ewald 2005).

In an earlier Swiss study aimed at assessing whether forest damage could be related to nutrient deficiencies, no signs of generalized deficiencies were found (Landolt et al. 1984). In this study, carried out 25 years ago, chemical analyses of needles were performed on Picea abies from 840 sites distributed systematically throughout Switzerland. At that time, however, the study aimed at detecting possible deficiencies in nutrients that had been identified as a key factor in forest decline elsewhere (e.g. magnesium; Zech and Popp 1983), and N was not analysed. Several other studies indicate, however, that the nitrogen status is still deficient to suboptimal for spruce stands in large areas in Switzerland. In 100 spruce stands in Canton Zurich in 1986, 70\% had foliar $\mathrm{N}$ and/or $\mathrm{P}$ concentrations below the optimum range (Landolt 1997). Schleppi et al. (2000) also measured foliar $\mathrm{N}$ concentrations below optimal levels in four spruce stands located in either the Pre-Alps or the Alps. $\mathrm{N}$ concentrations $>13 \mathrm{mg} \mathrm{g}^{-1}$ (lower value of the optimum range) were only found on the Swiss Plateau (three sites, in Landolt 1997). Likewise, Flückiger and Braun (1998) reported deficient or suboptimal foliar $\mathrm{N}$ levels in spruce stands at high elevations. Similar results showing a mineral nutrition in the deficiency range for $\mathrm{N}$ have also been reported for spruce in regions of France (Jura, Alps, Pyrenees; Landmann et al. 1994), Austria (Stefan 1991) and Germany (Gulder and Kölbel 1993), whereas $\mathrm{N}$ nutrition in the optimal range has been reported from other regions of France (Vosges, Ardennes; Landmann et al. 1994) and Central Europe (Mellert et al. 2004).

The availability of phosphorus also seems to be a factor influencing crown conditions, as indicated by the significant effect of the foliar P concentration in our model. Foliar ratios of $\mathrm{N}$ to $\mathrm{P}$ or $\mathrm{N}$ to base cations did not significantly improve the model, while other studies have found that unfavourable ratios were associated with poor crown conditions (e.g. Cape et al. 1990; Musio et al. 2007). However, an unfavourable foliar N/P ratio was measured at Novaggio, where unexplained defoliation was higher than that assessed on other broadleaves.

\section{Crown defoliation and other factors}

One major factor controlling crown condition is stand age, as documented by several studies (e.g. Ewald 2005; Klap et al. 2000). However, stand age (indicated as the maximum tree age) did not significantly improve our regression model, which might be due to the restricted range of the ages represented in our sample set (Table 1).

In an earlier study of crown conditions at around 160 Swiss permanent sites, relationships between defoliation and soil, climate and topography factors were explored for Picea abies, Abies alba, and Fagus sylvatica (Webster et al. 1996). No significant relationships were found for Fagus sylvatica, while crown defoliation was negatively correlated with the soil-water-holding capacity for both Picea and Abies. In addition, the carbonate content of the soil was positively correlated with defoliation for Abies. This relationship may be due to $\mathrm{N}, \mathrm{P}$, manganese (Mn), and $\mathrm{K}$ deficiencies induced by ion antagonism and high $\mathrm{pH}$ in calcareous soils (Zech 1969). It may also be interpreted, however, in terms of water availability, since high amounts of carbonates are found in shallow and stony soils. Liu et al. (1994) conjectured that the unfavourable combination of low $\mathrm{P}$ availability and low water storage capacity was involved in the needle loss observed in spruce stands in the calcareous Bavarian Alps. Water availability appeared thus to be a factor affecting crown condition.

In contrast with this finding, including the water-holding capacity in the model did not significantly improve the results with our limited sample set. One reason might be that this parameter alone does not reflect the potential water stress to which the trees may be subjected: the waterholding capacity should rather be combined with climatic factors. The analysis of the temporal variation in crown defoliation shows that drought is an important factor at the site level. Graf Pannatier et al. (2007) showed that crown defoliation at 13 LWF sites increased 1 year after the drought in 2003 proportionally to water deficits. However, when the spatial variation in average crown defoliation across our 17 sites was considered, the drought index of a site, calculated as the average ratio between actual and potential evapotranspiration (AET/PET), did not improve our regression model.

\section{Overview and conclusion}

The main results of this study can be summarized as follows: 
(i) Nitrate leaching was observed at sites subjected to $\mathrm{N}$ deposition $>10 \mathrm{~kg} \mathrm{ha}^{-1} \mathrm{a}^{-1}$ and where the $\mathrm{C} / \mathrm{N}$ ratio of the soil organic layer was below a certain threshold, as initially hypothesized (Hypothesis \#1). However, the threshold for the $\mathrm{C} / \mathrm{N}$ ratio should probably not be a fixed value of 25 (or 23). Rather, the information on the $\mathrm{N}$ status provided by the $\mathrm{C} / \mathrm{N}$ ratio should be combined with additional information on the pool of organic carbon in the soil and the humus type.

(ii) Foliar $\mathrm{N}$ concentrations were positively correlated to $\mathrm{N}$ deposition across our sites, for broadleaved species as well as for coniferous species, in line with Hypothesis \#2. Moreover, foliar N concentrations seemed to respond rather rapidly to changes in deposition, as their temporal variation paralleled that of $\mathrm{N}$ deposition, at least at some of our sites.

(iii) We found no relationship between $\mathrm{N}$ deposition and crown defoliation; therefore Hypothesis \#3, that crown conditions would deteriorate where deposition is high and in exceedance of the critical loads, has not been verified. On the contrary, poor crown conditions were more frequently observed in our coniferous stands, most of which are located at moderate to high elevations, where $\mathrm{N}$ deposition is rather low and below the critical loads. Foliar N concentrations in coniferous trees indicate a suboptimal to optimal $\mathrm{N}$ nutrition. The unexplained crown defoliation decreases, i.e. crown condition improves, with increasing foliar $\mathrm{N}$ concentrations. Chironico is the only coniferous site where $\mathrm{N}$ deposition clearly exceeds the critical loads. However, no negative effects are currently apparent as the foliar $\mathrm{N}$ concentrations lie within the optimum range, and the $\mathrm{C} / \mathrm{N}$ ratio of the forest floor indicates that the ecosystem can still retain the incoming nitrogen.

(iv) In our broadleaved stands, the unexplained crown defoliation did not correlate with the foliar $\mathrm{N}$ concentration. This could be related to the fact that $\mathrm{N}$ nutrition is optimal in the majority of the stands according to the foliar $\mathrm{N}$ concentrations.

(v) The $\mathrm{N}$ status of the site plays a major role in the fate of the deposited $\mathrm{N}$, which has to be taken into account when evaluating the risks related to high $\mathrm{N}$ deposition. This is illustrated by the two sites of Schänis and Novaggio, which both receive $\mathrm{N}$ deposition clearly above the critical loads for this element. At Schänis, the values of nitrate leaching indicate that this site has reached the saturation stage. However, although foliar $\mathrm{N}$ concentrations are slightly above the optimum range at Schänis, the foliar N/P ratio indicate a balanced nutrition for these two elements, and no negative effects (regarding crown condition) are apparent. On the other hand, at Novaggio, the foliar $\mathrm{N}$ concentrations are within the optimum range but the foliar N/P ratio is unfavourably high and is associated with a rather high unexplained defoliation. These observations are indicative of a possible stress even though nitrogen saturation, as indicated by nitrate leaching, has not yet been reached at this site.

Critical load exceedances are not necessarily associated with immediate negative effects. This is as expected since critical loads are designed to assess long-term effects and are calculated for a steady state while the forest ecosystem may still be in a transition phase. It is thus essential to continue to monitor and assess the potential risks of any ecosystem changes in these ecosystems.

Acknowledgments We are grateful to A. Brechbühl, N. Hajjar, O. Schramm, Y.Y. Cheung-Tang, D. Christen, A. Zürcher and former laboratory staff for sample handling in the field and in the laboratory; the staff from the forest services for collecting the samples on the LWF sites; C. Hug and the Sanasilva field crew; P. Suter for foliage sampling; D. Pezzotta and his team of the WSL central laboratory for analysing the samples, P. Jakob for the data-base support, F. Sutter for generating Fig. 1; M. Rebetez and G. Schneiter for climatic data; and S. Dingwall for editing the English. We gratefully acknowledge the financial support of the Federal Office for the Environment (FOEN).

\section{References}

Aber JD, Nadelhoffer KJ, Steudler P, Melillo JM (1989) Nitrogen saturation in northern forest ecosystems. BioSci 39:378-386

Aber J, McDowell W, Nadelhoffer K, Magill A, Berntson G, Kamakea M, McNulty S, Currie W, Rustad L, Fernandez I (1998) Nitrogen saturation in temperate forest ecosystemshypotheses revisited. BioSci 48:921-934

Achermann B, Bobbink R (2003) Empirical critical loads for nitrogen. In: Expert workshop held under the convention on long-range transboundary air pollution covering the region of the UNECE, Berne, 11-13 November 2002. Environmental Documentation. Swiss Agency for the Environment, Forests and Landscape, Berne

Arbeitskreis Standortskartierung (1996) Forstliche Standortaufnahme. Begriffe, Definitionen, Einteilungen, Kennzeichnungen, Erläuterungen, 5th edn. IHW-Verlag, München

Bergmann W (1993) Ernährungsstörungen bei Kulturpflanzen, 3rd edn. Gustav Fischer, Jena

Boggs JL, McNulty SG, Pardo LH (2007) Changes in conifer and deciduous forest foliar and forest floor chemistry and basal area tree growth across a nitrogen $(\mathrm{N})$ deposition gradient in the northeastern US. Environ Pollut 149:303-314

Borken W, Matzner E (2004) Nitrate leaching in forest soils: an analysis of long-term monitoring sites in Germany. J Plant Nutr Soil Sci 167:277-283

Boxman AW, Blanck K, Brandrud TE, Emmett BA, Gundersen P, Hogervorst RF, Kjønaas OJ, Persson H, Timmermann V (1998a) Vegetation and soil biota response to experimentally-changed nitrogen inputs in coniferous forest ecosystems of the NITREX project. For Ecol Manag 101:65-79 
Boxman AW, van der Ven PJM, Roelofs JGM (1998b) Ecosystem recovery after a decrease in nitrogen input to a Scots pine stand at Ysselsteyn, The Netherlands. For Ecol Manag 101:155-163

Brang P (1998) Sanasilva-Bericht 1997. Zustand und Gefährdung des Schweizer Waldes-eine Zwischenbilanz nach 15 Jahren Waldschadenforschung. Berichte WSL, vol 345. Swiss Federal Institute for Forest, Snow and Landscape Research, Birmensdorf

Cape JN, Freer-Smith PH, Paterson IS, Parkinson JA, Wolfenden J (1990) The nutritional status of Picea abies (L.) Karst. across Europe, and implications for forest decline. Trees 4:211-224

Cherubini P, Fontana G, Rigling D, Dobbertin M, Brang P, Innes JL (2002) Tree-life history prior to death: two fungal root pathogens affect tree-ring growth differently. J Ecol 90:839-850

De Vries W, Reinds GJ, van der Salm C, Draaijers GPJ, Bleeker A, Erisman JW, Auée J, Gundersen P, Kristensen HL, van Dobben H, de Zwart D, Derome J, Voogd JCH, Vel EM (2001) Intensive monitoring of forest ecosystems in Europe. Technical Report 2001 International Co-operative Programme on Assessment and Monitoring of Air Pollution Effects on Forests (ICP-Forests) Convention on Long-Range Transboundary Air Pollution (LRTAP). UN-ECE, Brussels

De Vries W, Vel E, Reinds GJ, Deelstra H, Klap JM, Leeters EEJM, Hendriks CMA, Kerkvoorden M, Landmann G, Herkendell J, Haussmann T, Erisman JW (2003) Intensive monitoring of forest ecosystems in Europe: 1. Objectives, set-up and evaluation strategy. For Ecol Manag 174:77-95

De Vries W, van der Salm C, Reinds GJ, Erisman JW (2007) Element fluxes through European forest ecosystems and their relationships with stand and site characteristics. Environ Pollut 148: 501-513

De Vries W, Solberg S, Dobbertin M, Sterba H, Laubhann D, Reinds GJ, Nabuurs G-J, Gundersen P, Sutton MA (2008) Ecologically implausible carbon response. Nature 451:E1-E3

Dise NB, Wright RF (1995) Nitrogen leaching from European forests in relation to nitrogen deposition. For Ecol Manag 71:153-161

Dise NB, Matzner E, Forsius M (1998) Evaluation of organic horizon $\mathrm{C}: \mathrm{N}$ ratio as an indicator of nitrate leaching in conifer forests across Europe. Environ Pollut 102:453-456

Dise NB, Rothwell JJ, Gauci V, van der Salm C, de Vries W (2009) Predicting dissolved inorganic nitrogen leaching in European forests using two independent databases. Sci Total Environ 407:1798-1808

Dobbertin M (2005) Tree growth as indicator of tree vitality and of tree reaction to environmental stress: a review. Eur J For Res 124:319-333

Dobbertin M, Rigling A (2006) Pine mistletoe (Viscum album ssp. austriacum) contributes to Scots pine (Pinus sylvestris) mortality in the Rhone valley of Switzerland. For Pathol 36:309-322

Dobbertin M, Hug C, Schwyzer A (2001) Aufnahmeanleitung für die Sanasilva-Inventur und Kronenansprachen auf den LWF-Flächen, Version 7.2, März 2001 Eidg. Forschungsanstalt für Wald, Schnee und Landschaft (WSL), Birmensdorf

Draaijers GPJ, Erisman JW (1995) A canopy budget model to assess atmospheric deposition from throughfall measurements. Water Air Soil Pollut 85:2253-2258

Eichhorn J, Haussmann T, Paar U, Reinds GJ, De Vries W (2001) Assessments of impacts of nitrogen deposition on beech forests: results from the Pan-European Intensive Monitoring Programme. TheScientificWorld 1:423-432. doi:10.1100/tsw.2001.325

EKL (2005) Stickstoffhaltige Luftschadstoffe in der Schweiz. StatusBericht der Eidg. Kommission für Lufthygiene (EKL). Schrreihe Umw, vol 384. Bundesamt für Umwelt, Wald und Landschaft (BUWAL), Bern

Evers FH (1972) Die jahrweisen Fluktuationen der Nährelementkonzentrationen in Fichtennadeln und ihre Bedeutung für die
Interpretation nadelanalytischer Befunde. Allg Forst-Jagdztg 143:68-74

Ewald J (2005) Ecological background of crown condition, growth and nutritional status of Picea abies (L.) Karst. in the Bavarian Alps. Eur J For Res 124:9-18

Flückiger W, Braun S (1998) Nitrogen deposition in Swiss forests and its possible relevance for leaf nutrient status, parasite attacks and soil acidification. Environ Pollut 102:69-76

Flückiger W, Braun S, Quiring R (1997) Wieviel Stickstoff ertragen unsere Wälder? In: "Säure- und Stickstoffbelastungen - Ein Risiko für den Schweizer Wald?”. Forum für Wissen 1997, Eidg. Forschungsanstalt für Wald, Schnee und Landschaft (WSL), Birmensdorf, pp 59-72

Forsius M, Kleemola S, Starr M (2005) Proton budgets for a monitoring network of European forested catchments: impacts of nitrogen and sulphur deposition. Ecol Indic 5:73-83

Gessler A, Schneider S, von Sengbusch D, Weber P, Hanemann U, Huber C, Rothe A, Kreutzer K, Rennenberg H (1998) Field and laboratory experiments on net uptake of nitrate and ammonium by the roots of spruce (Picea abies) and beech (Fagus sylvatica) trees. New Phyto 138:275-285

Graf Pannatier E, Walthert L, Blaser P (2004) Solution chemistry in acid forest soils: are the $\mathrm{BC}$ : $\mathrm{Al}$ ratios as critical as expected in Switzerland? J Plant Nutr Soil Sci 167:160-168

Graf Pannatier E, Dobbertin M, Schmitt M, Thimonier A, Waldner P (2007) Effects of the drought 2003 on forests in Swiss Level II plots. In: Eichhorn $\mathrm{J}$ (ed) Forests in a changing environmentresults of 20 years ICP forests monitoring, Göttingen, Germany, October 25-28, 2006. Schriften aus der Forstlichen Fakultät der Universität Göttingen und der Nordwestdeutschen Forstlichen Versuchsanstalt, vol. 142, pp 128-135

Grennfelt P, Thörnelöf E (1992) Critical loads for nitrogen-a workshop report, 1992, vol 41. Nordic Council of Ministers, Copenhagen

Gulder H-J, Kölbel M (1993) Waldbodeninventur in Bayern. Forstl Forschber Münch, vol 132

Gundersen P (1995) Nitrogen deposition and leaching in European forests-preliminary results from a data compilation. Water Air Soil Pollut 85:1179-1184

Gundersen P, Callesen I, de Vries W (1998a) Nitrate leaching in forest ecosystems is related to forest floor $\mathrm{C} / \mathrm{N}$ ratios. Environ Pollut 102:403-407

Gundersen P, Emmett BA, Kjønaas OJ, Koopmans CJ, Tietema A (1998b) Impact of nitrogen deposition on nitrogen cycling in forests: a synthesis of NITREX data. For Ecol Manage 101:37-55

Gundersen P, Schmidt IK, Raulund-Rasmussen K (2006) Leaching of nitrate from temperate forests-effects of air pollution and forest management. Environ Rev 14:1-57

Huber C, Kreutzer K, Rohle H, Rothe A (2004) Response of artificial acid irrigation, liming, and $\mathrm{N}$-fertilisation on elemental concentrations in needles, litter fluxes, volume increment, and crown transparency of a N saturated Norway spruce stand. For Ecol Manag 200:3-21

Hüttl RF (1990) Nutrient supply and fertilizer experiments in view of N saturation. Plant Soil 128:45-58

Kandler O (1994) Vierzehn Jahre Waldschadendiskussion. Natwiss Rundsch 47:419-430

Kjønaas OJ, Stuanes AO, Huse M (1998) Effects of weekly nitrogen additions on $\mathrm{N}$ cycling in a coniferous forest catchment, Gårdsjön, Sweden. For Ecol Manag 101:227-249

Klap JM, Voshaar JHO, De Vries W, Erisman JW (2000) Effects of environmental stress on forest crown condition in Europe. Part IV: Statistical analysis of relationships. Water Air Soil Pollut 119:387-420

Körner C (1989) The nutritional status of plants from high altitudesa worldwide comparison. Oecologia 81:379-391 
Kristensen HL, Gundersen P, Callesen I, Reinds GJ (2004) Throughfall nitrogen deposition has different impacts on soil solution nitrate concentration in European coniferous and deciduous forests. Ecosystems 7:180-192

Lamersdorf NP, Borken W (2004) Clean rain promotes fine root growth and soil respiration in a Norway spruce forest. Glob Chang Biol 10:1351-1362

Landmann G, Bonneau M, Bouhot-Delduc L, Fromard F, Chéret V, Dagnac JS, Souchier B (1994) Crown damage in Norway spruce and silver fir: relation to nutritional status and soil chemical characteristics in the French mountains. In: Landmann G, Bonneau M (eds) Forest decline and atmospheric deposition effects in the French mountains. Springer, Berlin, pp 41-81

Landolt E (1977) Ökologische Zeigerwerte zur Schweizer Flora. Veröffentlichungen des geobotanischen Institutes der Eidg Techn Hochschule, vol 64. Stiftung Rübel, Zürich

Landolt W (1997) Mangel oder Überfluss? Zur Ernährungssituation von Fichten. In: Säure- und Stickstoffbelastungen-Ein Risiko für den Schweizer Wald? Forum für Wissen 1997, Eidg. Forschungsanstalt für Wald, Schnee und Landschaft (WSL), Birmensdorf, pp 51-58

Landolt W, Bucher JB, Kaufmann E (1984) Waldschäden in der Schweiz-1983 (II. Teil). Schweiz Z Forstwes 135:637-653

Laubhann D, Sterba H, Reinds GJ, De Vries W (2009) The impact of atmospheric deposition and climate on forest growth in European monitoring plots: an individual tree growth model. For Ecol Manag 258:1751-1761

Liu J, Keller T, Runkel K, Payer H (1994) Bodenkundliche Untersuchungen zu Ursachen des Nadelverlusts der Fichten (Picea abies [L.] Karst.) auf Kalkstandorten der Alpen. Forstwiss Centbl 113:86-100

Lövblad G, Tarrasón L, Tørseth K, Dutchak S (eds) (2004) EMEP assessment-Part I-European perspective (http://www.emep. int/assessment/Part1/). Norwegian Meteorological Institute, Oslo

MacDonald JA, Dise NB, Matzner E, Armbruster M, Gundersen P, Forsius M (2002) Nitrogen input together with ecosystem nitrogen enrichment predict nitrate leaching from European forests. Glob Chang Biol 8:1028-1033

McNulty SG, Boggs J, Aber JD, Rustad L, Magill A (2005) Red spruce ecosystem level changes following 14 years of chronic $\mathrm{N}$ fertilization. For Ecol Manag 219:279-291

Mellert KH, Prietzel J, Straussberger R, Rehfuess KE (2004) Longterm nutritional trends of conifer stands in Europe: results from the RECOGNITION project. Eur J For Res 123:305-319

Mohn J, Schurmann A, Hagedorn F, Schleppi P, Bachofen R (2000) Increased rates of denitrification in nitrogen-treated forest soils. For Ecol Manag 137:113-119

Müller E, Stierlin HR (1990) Sanasilva-Kronenbilder mit Nadel- und Blattverlustprozenten. 2. Überarbeitete und erweiterte Auflage. Eidgenössische Forschungsanstalt für Wald, Schnee und Landschaft (WSL), Birmensdorf

Musio M, von Wilpert K, Augustin N (2007) Crown condition as a function of soil, site and tree characteristics. Eur J For Res 126:91-100

Neirynck J, Janssens I, Roskams P, Quataert P, Verschelde P, Ceulemans R (2008) Nitrogen biogeochemistry of a mature Scots pine forest subjected to high nitrogen loads. Biogeochem 91:201-222

Nilsson J, Grennfelt P (1988) Critical loads for sulphur and nitrogen. Workshop in Skokloster, Sweden, 19-24 March 1988. Nordic Council of Ministers, Copenhagen

Ortloff W, Schlaepfer R (1996) Stickstoff und Waldschäden: eine Literaturübersicht. Allg Forst-Jagdztg 167:184-201

Providoli I, Bugmann H, Siegwolf R, Buchmann N, Schleppi P (2005) Flow of deposited inorganic $\mathrm{N}$ in two Gleysol-dominated mountain catchments traced with ${ }^{15} \mathrm{NO}_{3}{ }^{-}$and ${ }^{15} \mathrm{NH}_{4}{ }^{+}$. Biogeochem 76:453-475

Providoli I, Bugmann H, Siegwolf R, Buchmann N, Schleppi P (2006) Pathways and dynamics of ${ }^{15} \mathrm{NO}_{3}{ }^{-}$and ${ }^{15} \mathrm{NH}_{4}{ }^{+}$applied in a mountain Picea abies forest and in a nearby meadow in central Switzerland. Soil Biol Biochem 38:1645-1657

Rihm B (1996) Critical loads of nitrogen and their exceedanceseutrophying atmospheric deposition. Environmental SeriesAir, 275. Federal Office of Environment, Forests and Landscape (FOEFL), Bern

Rihm B, Kurz D (2001) Deposition and critical loads of nitrogen in Switzerland. Water Air Soil Pollut 130:1223-1228

Roelofs JGM, Kempers AJ, Houdijk ALFM, Jansen J (1985) The effect of air-borne ammonium sulphate on Pinus nigra var. maritima in the Netherlands. Plant Soil 84:45-56

SAS Institute Inc (2002-2005) SAS OnlineDoc 9.1.3. SAS Institute Inc., Cary

Schleppi P, Tobler L, Bucher JB, Wyttenbach A (2000) Multivariate interpretation of the foliar chemical composition of Norway spruce (Picea abies). Plant Soil 219:251-262

Schleppi P, Hagedorn F, Providoli I (2004) Nitrate leaching from a mountain forest ecosystem with gleysols subjected to experimentally increased $\mathrm{N}$ deposition. Water Air Soil Pollut: Focus 4:453-467

Schmitt M, Thoni L, Waldner P, Thimonier A (2005) Total deposition of nitrogen on Swiss long-term forest ecosystem research (LWF) plots: comparison of the throughfall and the inferential method. Atmos Environ 39:1079-1091

Smidt S (2007) 10 Jahre Depositionsmessung im Rahmen des europäischen Waldschadensmonitorings. Ergebnisse 19962005. BFW-Berichte, 138. Bundesforschungs- und Ausbildungszentrum für Wald, Naturgefahren und Landschaft, Wien

Solberg S, Dobbertin M, Reinds GJ, Lange H, Andreassen K, Fernandez PG, Hildingsson A, de Vries W (2009) Analyses of the impact of changes in atmospheric deposition and climate on forest growth in European monitoring plots: a stand growth approach. For Ecol Manag 258:1735-1750

Starr M (1999) WATBAL: A model for estimating monthly water balance components, including soil water fluxes. In: Kleemola S, Forsius M (eds) 8th Annual Report 1999 International cooperative programme on integrated monitoring of air pollution effects on ecosystems UN ECE convention on long-range transboundary air pollution working group on effects. The Finnish Environment, vol 325. Finnish Environment Institute, Helsinki, pp 21-25

Stefan K (1991) Das österreichische Bioindikatornetz - Ergebnisse der Schwefel- und Nährelementuntersuchungen. VDI-Berichte 901:259-273

Stefan K, Fürst A, Hacker R, Bartels U (1997) Forest foliar condition in Europe-results of large-scale foliar chemistry surveys (survey 1995 and data from previous years). EC-UN/ECE, Austrian Federal Forest Research Centre, Brussels

Stefan K, Raitio H, Bartels U, Fürst A (2000) Part IV: sampling and analysis of needles and leaves. In: Manual on methods and criteria for harmonized sampling, assessment, monitoring and analysis of the effects of air pollution on forests. UN-ECE, Convention on Long-Range Transboundary Air Pollution (LRTAP). International Co-operative Programme on Assessment and Monitoring of Air Pollution Effects on Forests (ICPForests), Hamburg, p 77

Tamm CO (1991) Nitrogen in terrestrial ecosystems (Ecological Studies 81). Springer, Berlin

Thimonier A, Schmitt M, Waldner P, Rihm B (2005) Atmospheric deposition on Swiss Long-term Forest Ecosystem Research (LWF) plots. Environ Monit Assess 104:81-118 
Tietema A, Beier C (1995) A correlative evaluation of nitrogen cycling in the forest ecosystems of the EC projects NITREX and EXMAN. For Ecol Manag 71:143-151

Tietema A, Wright RF, Blanck K, Boxman AW, Bredemeier M, Emmett BA, Gundersen P, Hultberg H, Kjønaas OJ, Moldan F, Roelofs JGM, Schleppi P, Stuanes AO, van Breemen N (1995) NITREX: the timing of response of coniferous forest ecosystems to experimentally-changed nitrogen deposition. Water Air Soil Pollut 85:1623-1628

UBA (1996) Manual on methodologies and criteria for mapping critical levels/loads and geographical areas where they are exceeded. Texte, 71/96. Federal Environmental Agency (Umweltbundesamt), Berlin

Ulrich B (1983) Interaction of forest canopies with atmospheric constituents: SO2, alkali and earth alkali cations and chloride. In: Ulrich B, Pankrath J (eds) Effects of accumulation of air pollutants in forest ecosystems. Reidel, Dordrecht, pp 33-45

Van den Burg J (1990) Foliar analysis for determination of tree nutrient status - a compilation of literature data. Rijksinstituut voor Onderzoek un de Bos- en Landschapsbouw "De Dorschkamp", Rapport Nr 591, Wageningen

Van der Salm C, de Vries W, Reinds GJ, Dise NB (2007) N leaching across European forests: derivation and validation of empirical relationships using data from intensive monitoring plots. For Ecol Manag 238:81-91

Van Dijk HFG, de Louw MHJ, Roelofs JGM, Verburgh JJ (1990) Impact of artificial, ammonium-enriched rainwater on soils and young coniferous trees in a greenhouse. Part II-effects on the trees. Environ Pollut 63:41-59
Vervaet H, Massart B, Boeckx P, Van Cleemput O, Hofman G (2002) Use of principal component analysis to assess factors controlling net $\mathrm{N}$ mineralization in deciduous and coniferous forest soils. Biol Fertil Soils 36:93-101

Vitousek PM, Howarth RW (1991) Nitrogen limitation on land and in the sea-how can it occur? Biogeochem 13:87-115

Waldner P, Schaub M, Graf Pannatier E, Schmitt M, Thimonier A, Walthert L (2007) Atmospheric deposition and ozone levels in Swiss forests: are critical values exceeded? Environ Monit Assess 128:5-17

Walthert L, Blaser P, Lüscher P, Luster J, Zimmermann S (2003) Langfristige Waldökosystem-Forschung LWF in der Schweiz. Kernprojekt Bodenmatrix. Ergebnisse der ersten Erhebung 1994-1999. E-Collection, http://e-collectionethbibethzch/show? type=bericht\&nr=276, 276. Swiss Federal Institute of Technology, Zürich

Webster R, Rigling A, Walthert L (1996) An analysis of crown condition of Picea, Fagus und Abies in relation to environment in Switzerland. Forestry 69:347-355

Yin X (1992) Empirical relationships between temperature and nitrogen availability across North American forests. Can J For Res 22:707-712

Zech W (1969) Besonderheiten im Ernährungszustand chlorotischer Fichten auf kalkreichen Böden. Forstwiss Centbl 88:1-9

Zech W, Popp E (1983) Magnesiummangel—einer der Gründe für das Fichten- und Tannensterben in NO-Bayern. Forstwiss Centbl 105:421-435 